\title{
RESTAURAÇÃO, REINVENÇÃO E RECORDAÇÃO: RECUPERANDO IDENTIDADES SOB A ESCRAVIZAÇ̄̃O NA ÁFRICA E FACE À ESCRAVIDÃO NO BRASIL*
}

\author{
Joseph C. Miller \\ Virginia University - Estados Unidos
}

\begin{abstract}
Resumo
O artigo propõe uma leitura criativa e "especulativa" das experiências dos africanos que, por sua escravização, conectaram a África à América, e a América à África durante a época do comércio de escravos. Dialogando com a historiografia da escravidão nas Américas, com especial atenção para os historiadores brasileiros, a discussão focaliza a elaboração e invenção de identidades para além da polarização simplista do debate entre os partidários dos "africanismos" e os defensores da "crioulização". Tentando compreender a escravidão nos termos em que esta era pensada pelos próprios africanos e seus descendentes e mais como um processo histórico do que uma "instituição" abstrata, Miller mostra que a busca por laços sociais e constituição de novas comunidades eram os meios capazes de neutralizar a dispersão, a violência e o isolamento da escravização. Em outras palavras, eles re-estabeleceram os sentimentos de pertencimento e de segurança pessoal mínimos. Das confrarias religiosas e das comunidades de refugiados, às maltas de capoeira, aos reinados congos e às associações de ajuda mútua, dos anos formativos (séculos XVI ao XVII) da sociedade luso-brasileira, passando pelo século XVIII e chegando ao Brasil independente, o artigo acompanha processos complexos de constituição de conexões que, segundo Miller, só podem ser lidos numa perspectiva histórica pautada pela compreensão do tema em diferentes contextos e momentos da sociedade escravista e em suas articulações com uma África de muitos significados.
\end{abstract}

\section{Pallavras-chave}

Identidades africanas • América portuguesa/Brasil • comunidades escravas • séculos XVII ao XIX.

\author{
Correspondência \\ Virginia University \\ P.O. Box 400180 \\ Charlottesville - VA 22903 - Estados Unidos \\ E-mail: jmiller@virginia.edu
}

\footnotetext{
Originalmente publicado em CURTO, José C. e LOVEJOY, Paul E. (ed.). Enslaving connections: changing cultures of Africa and Brazil during the era of slavery. Amherst, NY: Humanity Books, 2004, p. 81-121. Tradução de Marilia Bandeira, Márcio Amêndola de Oliveira, Elisângela Queirós e Maria Cristina Cortez Wissenbach. Os editores da Revista de História agradecem a permissão da publicação do capítulo, em especial ao autor, aos organizadores da coletânea e à editora responsável pelo livro; e à colaboração de, Regina Nogueira e Mary Anne Junqueira na ajuda essencial à tradução. Os tradutores anotaram nas notas de referência as versões em português de obras citadas na edição original em inglês. $\mathrm{O}$ autor, revendo o texto para esta publicação, adverte que as referências incluídas nas notas não foram atualizadas desde a publicação do texto em 2004. Nesse sentido, as notas não se referem a obras que não tinham sido editadas na época e não abordam os estudos feitos posteriormente, principalmente em português. Alguns deles desenvolveram pontos oferecidos aqui como especulação e outros apontaram processos diferentes daqueles sugeridos no texto escrito em 2003.
} 


\title{
RETENTION, REINVENTION AND REMEMBERING: RESTORING IDENTITIES THROUGH ENSLAVEMENT IN AFRICA AND UNDER SLAVERY IN BRAZIL*
}

\author{
Joseph C. Miller \\ Virginia University - United States of America
}

\section{Abstract}

The article proposes a creative, and "speculative" reading of the experiences of Africans who, by their enslavement, connected Africa to America, and America to Africa, during the Atlantic slave trade. Engaging the historiography of slavery in the Americas, with particular attention to historians of Brazil, the discussion focuses on the elaboration and invention of identities within slavery in the Americas beyond the simplistic and polarized contrast debated between supporters of "africanismos" and proponents of "crioulização". Trying to understand slavery as it was conceived by Africans themselves and their descendants and as a historical process rather than an abstract "institution", Miller shows that the enslaved searched for social ties and built new communities as means of neutralizing the dispersion, violence and isolation of their enslavement. In other words, they re-established many senses of belonging and personal security. From religious confraternities and refugee communities, to capoeira maltas, congos "kings", and mutual aid associations, from the formative years of Brazilian society (16th to 17 th centuries), on through the 18 th century, and into politically independent 19 th-century Brazil, this article proposes complex processes of forming connections that, according to Miller, can be read only through a historical perspective and by understanding themes in different contexts and moments of the slave society and in their multiple connections with Africa.

\section{Keywords}

African identities $\bullet$ Portuguese America/Brazil $\bullet$ slave communities $\bullet 17^{\text {th }}$ to $19^{\text {th }}$ centuries.

Contact

Virginia University

P.O. Box 400180

Charlottesville, VA 22903 - United States of America

E-mail: jmiller@virginia.edu

Originally published in CURTO, José; LOVEJOY, Paul e. (eds.). Enslaving connections: changing cultures of Africa and Brazil during the era of slavery. Amherst, NY: Humanity Books, 2004, p. 81-121. Translation of Marilia Bandeira, Márcio Amêndola de Oliveira e Maria Cristina Cortez Wissenbach. The editors of Revista de História thank the permission of the publication of the chapter, in particular to the author, the organizers of the compilation and the publisher responsible for the book. Thanks also the collaboration essential to translation of Elisângela Queirós, Regina Nogueira and Mary Anne Junqueira. Translators noted in footnotes versions in Portuguese of the works cited in the original English edition. The author, reviewing the text for this publication, warns that the references included in the notes have not been updated since the publication of the text in 2004. Accordingly, the notes do not refer to works that had not been edited at the time and do not cover studies done subsequently, mainly in Portuguese. Some of these developed points offered here as speculation, and others identified processes other than those suggested in the text, written in 2003. 
Esta é uma investigação especulativa ${ }^{1}$ de como os estudiosos poderiam entender as experiências dos africanos que, por sua escravização, conectaram a África à América, e a América à África durante a época do comércio de escravos. Isto é, entender o que eles retiveram, como reinventaram e recordaram o que abandonaram. Trato este assunto atualmente em voga a partir da premissa metodologicamente desafiadora e conceitualmente radical - é como eu a vejo de que poderemos fazê-lo de forma mais produtiva, explorando as questões da mesma forma que as pessoas forçadas aos navios negreiros viam-nas.

Esse exercício fundamentalmente histórico pode chocar os puristas metodológicos como algo perigosamente conjectural, em razão da ausência de um testemunho verbal direto sobre aquilo que mais importava ou mais motivava os escravizados. E pode ser que sim, mas as outras alternativas são ainda mais especulativas, uma vez que elas dependem da projeção da visão de mundo dos senhores ou - ainda pior - da conceitualização dos especuladores criada sob o manto dos teóricos e historiadores modernos.

Um exame mais detalhado da lógica dos meios convencionais de manejar a experiência da escravidão por meio das abstrações sociológicas e culturais dúbias revela tantas suposições quanto aquelas em que esta proposta historicizante se apoia, tão problemáticas ou tão pouco comprovadas do que a que pretendo adotar. Abordar o problema da maneira que proponho aqui é um pré-requisito para que pesquisadores diligentes possam encontrar respostas plausíveis e até mesmo prováveis para isso, não por meio da tentativa de "ler os lábios" dos silenciados pelas fontes escritas, mas observando as ações daqueles que se expressaram por valores que trouxeram consigo da África e que foram ameaçados pela sua experiência de escravização.

O que estou propondo é historicizar a discussão que atualmente se coloca nos termos polarizados de "sobrevivências" da(s) cultura(s) africana(s) contra a

Por conseguinte, este ensaio é apresentado sem uma tentativa sistemática de citar as ricas, diversas e atuais vertentes historiográficas nas quais me baseio, da "história atlântica", da "diáspora africana" e do "Atlântico negro", às vertentes africanistas e aos esforços pós-estruturalistas em historicizar as interpretações quase a-históricas que, geralmente, se fizeram passar por "história", bem como outras correntes familiares aos leitores. Explorei, de forma preliminar, algumas dessas questões tal como aparecem na historiografia da África em: MILLER, Joseph C. History and Africa / Africa and history. American Historical Review 104, vol. 1, 1999, p. 1-32. A presente discussão reelabora, em parte, pontos esboçados em MILLER, Joseph C. Central Africa during the era of the slave trade, c. 1490s-1850s. In: HEYWOOD, Linda (ed.). Central Africans and cultural transformation in the America diaspora. Nova York: Cambridge University Press, 2002, p. 21-69. [Nota de tradução: África Central durante a era do comércio de escravizados de 1490 a 1850. In: HEYWOOD, Linda (ed.). Diápora negra no Brasil. Tradução de Ingrid de Castro Compean Fregonez, Thaís Cristina Casson e Vera Lúcia Benedito. São Paulo: Contexto, 2008, p. 29-80]. 
"crioulização"; isto é, perceber a maneira pela qual os africanos no Novo Mundo se moveram de um não problematizado Velho Mundo, para sobreviver na igualmente não problematizada brutalidade de sua escravização e da consequente exclusão imposta pelo racismo. Detectar "traços" selecionados, abstraídos e reificados da África na América ou numa "etnicidade" vista como um tipo de projeção humanizada de "cultura", como o principal aspecto das maneiras pelas quais os africanos se identificavam, buscando medidas de respeito no interior da degradação provocada pela escravidão, tem sido a estratégia dominante desde que Melville Herkovits insistiu, na década de 1930, de forma pioneira, na integridade da(s) “cultura(s)" etnicizada(s) na África, e sua ressurreição nas Américas. Ou seja, o debate ainda se apoia nas compreensões rudimentares do passado africano, de forma a poder identificá-lo com as teorias disponibilizadas pela escola moderna no continente, produzidas há mais de meio século.

Atualmente, existem crescentes e sofisticadas pesquisas sobre a história da África e da antropologia histórica que, se utilizadas, permitirão nos movermos para além do entendimento do que os africanos podem ter criado, compreendendo como e porque eles o criaram e, nessas bases, conferindo maior complexidade e confiabilidade ao estudo sobre as experiências dos escravizados. Mais do que isso, temos aprendido a ler os relatos pessoais dos sobreviventes - existentes em número maior do que havia sido imaginado - com uma perspicácia que vai além das palavras empregadas quando lhes era pedido que se identificassem perante seus inquisidores, senhores e polícia, ou quaisquer outros que pretendessem usar contra eles qualquer coisa dita. O discurso singular da rotulação étnica que chegava aos ouvidos dos que escreviam era calculado para dizer a eles o que eles queriam ouvir, e esconder o que o escravizado de fato pensava ou desejava.

Finalmente, uma atenção maior à experiência da escravidão propriamente dita no Novo Mundo permite-nos agora compreender e frequentemente documentar como os comportamentos registrados dos escravizados expressaram esses outros sentidos de si próprios. Sentidos mais autônomos e mais africanos do que meras reações, adaptações, ou assimilações às normas de seus senhores, algumas vezes até mesmo quando codificados em termos cristãos e europeus. Talvez nenhum outro contexto histórico seja mais favorável do que a escravidão na destruição ou manipulação das identidades dos outros, e, portanto, com maior tendência à má interpretação do "ser", de ambos os lados. Não estou inclinado a tomar qualquer um dos lados "ao pé da letra", mas encorajado a interpretar as palavras que eles usaram de acordo com o contexto - os "desentendimentos operacionais" que eu estenderia para enfatizar a possibilidade de "fraudes calculadas" - nas quais as pessoas as empregaram. 
$\mathrm{O}$ argumento aqui considera as percepções e as prioridades dos africanos, escondidas sob conceitos ideológicos dos que foram compelidos a se declararem "fortes", e que motivaram as ações daqueles que eles rejeitaram como "fracos". As motivações dos escravizados - centradas na dor do isolamento inicial, na subsequente individualização, e na errância recorrente e potencialmente sem fim no mundo cada vez mais mercantil do Atlântico - bem como a principal perda que preocupava praticamente todos os oriundos da África e que chegaram ao Brasil (ou a qualquer outro lugar das Américas) que era a violação de suas dignidades, que buscaram mais ardentemente superar. ${ }^{2}$

Num tempo anterior ao que a ciência médica sonhou assegurar a integridade do corpo, as únicas esferas da vida sobre as quais todo mundo desejava ter controle eram as da integridade do espírito e da comunidade. Dor e morte não poderiam ser evitadas, mas poder-se-ia buscar consolo na companhia uns dos outros. As pessoas, portanto, construíram identidades de um tipo social primário - e as identidades africanas que os escravos haviam perdido na captura e remoção forçada para as Américas eram pensáveis e mantidas por meio da conexão com os outros, certamente significativas e com o propósito de estruturar uma interpretação coerente daquilo que fizeram em escala continental e durante os múltiplos séculos aqui considerados. Para eles, a famosa caracterização de Orlando Patterson da escravização como "morte social” carregava um profundo senso de não existência pessoal.

Podemos entender as ações dos africanos como uma busca recorrente, predominantemente para obter um lugar reconhecido nas comunidades do Novo Mundo, como expressa o subtítulo do meu artigo, "recuperando identidades sob a escravização na África e face à escravidão no Brasil". Todos os escravos, em todos os lugares, construíram vidas próprias sob a escravidão, desde que lhes fosse permitido

\footnotetext{
2 Minha ênfase sobre as buscas dos africanos escravizados por conexões historiciza uma ideia central da famosa definição de Orlando Patterson sobre escravidão, invocando as concepções mais recentes de identidade, pessoal e coletiva. Ver sua obra: PATTERSON, Orlando. Slavery and social death: A comparative study. Cambridge, Mass.: Harvard University Press, 1982, p. 12: " a dominação permanente e violenta das pessoas alienadas ao nascerem [isto é, desenraizadas] e geralmente desonradas" (do autor o itálico, meu destaque entre chaves). Minha atenção sobre este aspecto das conexões dos escravizados foi moldada pela leitura da aplicação da definição de Orlando Patterson aos escravos do cabo da Boa Esperança feita por MASON, John Edwin. Social death and ressurection: Slavery and emancipation in South Africa. Charlottesville: University of Virginia Press, 2003; e em TROUTMAN, Philip. Slave trade and sentiment in Antebellum Virginia. Dissertação de Ph.D., University of Virginia, 2000. Para uma explanação bem desenvolvida da complexidade e da multiplicidade das identidades sob a escravização (embora com ênfase diferente), ver LOVEJOY, Paul E. e LAW, Robin. Introdução. In: LOVEJOY \& LAW (ed.). The biography of Muhammad Gardo Baquaqua. Princeton: Markus Wiener, 2001.
} 
permanecer num lugar tempo suficiente para consolidar as conexões sociais que validavam o "ser" de qualquer um - a família, os companheiros de navio, a família senhorial e muitas outras que os escravizados criaram para si mesmos no Brasil.

A vulnerabilidade das pessoas encurraladas na escravidão não pode ser equiparada com passividade, ou mesmo vitimização, tampouco como estratégia estreita de sobrevivência. No entanto, no meio ambiente capitalista do Atlântico, seu status legal e civil de "propriedades" intercambiáveis e móveis, os separava repetidamente por meio de venda ou de alguma outra forma de transferência, com o objetivo de ganho econômico para alguém, expondo-os novamente à vulnerabilidade essencial de sua escravidão: de estarem sós novamente, talvez incapazes de se comunicarem, desconhecendo as regras do jogo no qual se encontravam encurralados, ignorantes dos fatores impingidos à sua sobrevivência diária.

Para o escravizado, a sobrevivência significava, para além do sentido meramente físico, uma reconstrução constante de novas conexões na sucessão de circunstâncias transitórias às quais a maioria foi compelida, um esforço recorrente de encontrar seus lugares próprios e de pertencer, de alguma forma, a algum lugar. Para ele o peso da escravidão comercializada não era a servidão por si só, mas principalmente a traição da responsabilidade dos senhores que os venderam ou os transferiram com o propósito de ganhos pessoais. Ao traçar as lutas dos escravos para se reconstituírem por meio da formação de comunidades, vistas como estratégias psicológicas e históricas pelas quais estabeleceram sua presença no Brasil, é possível percebê-los como agentes atuando de forma independente diante da minoria europeia nomeadamente no poder. Considerando os escravizados em termos de suas estratégias, é possível entender as eras do Brasil colonial e as fases iniciais do Império como "africanas", da mesma forma que as interpretações convencionais dão ênfase ao contexto português da elite letrada ou culta do país.

Interpretando as conexões "escravizantes" do Brasil com a África, como a busca dos escravizados por suas próprias conexões, os estudiosos devem estabelecer a presença de uma autonomia africana que pode validar o completo engajamento dialético por meio do qual africanos e europeus, unidos em conflito, trabalharam a sucessão de acomodações tensas que vieram a se tornar o Brasil ou qualquer outra parte das Américas - e sublinharam a extensão pela qual toda identidade no Novo Mundo veio a ser um produto da confrontação do complexo contexto humano do Atlântico. ${ }^{3}$

3 Um aparte epistemológico: se a história procede de confrontações dialéticas, como eu acredito, a consideração da dialética como a principal e mesmo a mais significativa reação aos outros não permite estabelecer a independência de motivação e a estratégia necessária para uma síntese que 


\section{As premissas: as mentalidades africanas}

Restringindo a percepção deste processo ao Brasil - uma vez que oferece instâncias extremas e, portanto, analiticamente úteis de tendências demográficas encontradas por todas as partes das Américas - o percurso começa por meio do reconhecimento de que as pessoas nascidas e cognitivamente moldadas na África foram maioria na fase mais dinâmica da formação de todos os centros nos quais as identidades brasileiras tomaram forma. Apesar das fronteiras brasileiras do Nordeste, no século XVI, até as do Norte e do Oeste no final do século XIX, em que floresciam as interações entre ameríndios e europeus, ${ }^{4}$ e diferentemente da influência das maiorias nativas na construção da identidade moderna no México e outras regiões hispânicas das Américas, as confrontações que vieram a ser o "Brasil" surgiram das massas de africanos escravizados que inundaram a colônia portuguesa e construíram as capitanias de açúcar e de mineração, na Bahia e em Pernambuco, no final do século XVI, nas Minas e no Rio de Janeiro no XVIII, e na província de São Paulo, no início do século XIX.

Apesar também da alta mortalidade entre os africanos que chegavam ao Brasil e nas frotas de negreiros que traziam reposições da África em número significativo, até os meados do século XIX, ${ }^{5}$ e da tendência de serem aceitos como brasileiros seus descendentes aqui nascidos, as pessoas nativas da África predominaram entre aquelas mantidas na escravidão em maior grau do que em qualquer outro lugar nas Américas. ${ }^{6}$ Então, esses africanos, distintos de seus des-

vai além da mera extensão da agenda do grupo dominante. Sem considerar a parte efetiva da autonomia na dialética, a história torna-se determinista e teleológica, a história dos "vencedores" e a de suas vítimas. No caso do Brasil e da África, resultados verdadeiramente históricos foram frutos das lutas não diretamente competitivas entre africanos desesperados para recolocar e substituir a comunidade que eles perderam e as lutas dos europeus para recuperar falhas comerciais.

4 Ver as recentes interpretações sobre Palmares que enfatizam a presença dos nativos americanos na comunidade maroon da primeira metade do século XVII, normalmente celebrada pela presença de africanos entre seus residentes; por exemplo, FUNARI, Pedro Paulo. A arqueologia de Palmares: sua contribuição para o conhecimento da história da cultura afro-americana. In: REIS, João Jose e GOMES, Flávio (ed.). Liberdade por um fio: história dos quilombos no Brasil. São Paulo: Companhia das Letras, 1996, p. 26-51.

5 FLORENTINO, Manolo Garcia. Em costas negras: uma história do tráfico Atlântico de escravos entre a África e o Rio de Janeiro (séculos XVIII e XIX). São Paulo: Companhia das Letras, 1997; MILLER, Joseph C. Way of death: Merchant capitalism and the Angolan slave trade, 1730-1830. Madison: University of Wisconsin Press, 1988. Para o "tráfico ilegal" de escravos do século XIX, ver FERREIRA, Roquinaldo do Amaral. Dos sertões ao Atlântico: tráfico ilegal de escravos e comércio lícito em Angola, 1830-1860. Dissertação de mestrado, Universidade Federal do Rio de Janeiro, Instituto de Filosofia e Ciências Sociais, Programa de Pós-graduação em História Social, s.d., 1997.

6 Este fato é mais importante do que tem sido geralmente apreciado. Desde 1998, eu venho dirigindo o National Endowment for the Humanities Summer Institutes, baseado na premissa de que 
cendentes afro-brasileiros, fizeram da África e de suas "conexões escravizantes" um ponto de partida necessário para a compreensão da formação do Brasil. Dessa maneira, ao invés de partir das lutas dos escravos contra seus senhores, deve-se começar pela busca das estratégias dos escravizados olhando suas experiências na África, quem eles pensavam ter sido quando vendidos na África, o que perderam, e como buscaram recuperar-se dessa experiência. Para ver o Brasil nestes termos, como um país africano, os acadêmicos devem enxergar a África para além das suposições modernistas que estruturaram, até agora, a maioria dos esforços para entender a história do continente e, por extensão, a diáspora negra, a história das Américas e a escravidão em todas as partes do Atlântico.

Os mitos sobre a África que prevalecem na cultura popular, sejam eles racistas ou românticos, também derivam dos conceitos da era colonial sobre os africanos como ausentes ou distintos dos valores da modernidade e, portanto, oferecem olhares limitados que se desviam das diferentes estratégias e percepções que os estudiosos mais atuais revelam ter existido entre os africanos. A coerência de uma visão alternativa emergente depende do abandono de um conjunto compreensivo e politizado de suposições herdadas de construções equivocadas do racismo do século XX. E, mesmo os estudiosos mais experientes nos estilos da história que prevaleceram em outras regiões do mundo ainda lutam para entender a África em outras premissas que não as interpretações benignas e antigas, extremamente parciais, quando não altamente equivocadas. ${ }^{7}$ Se então reduzirmos o edifício familiar da academia a uma construção menor e olharmos para além da modernidade, que é uma grande parte de todos nós, quais seriam as inferências da África por

os professores da história e da cultura da América do Norte não podem compreender os anos de formação do que viria a se tornar os Estados Unidos sem conhecer a África e os africanos escravizados que vieram de lá, da mesma forma que é importante entender a Inglaterra elizabetana; ver o web site Roots: The African dimensions of early American history and culture, $<$ http://www. virginia.edu/vfh/roots $>$. Tenho consciência dos recentes estudos demográficos que identificam bolsões antigos e isolados de crescimento populacional construídos por afro-brasileiros em Minas Gerais e outras partes, convenientemente resumidos em KLEIN, Herbert S. The Atlantic slave trade. Nova York: Cambridge University Press, 1999.

7 Com os créditos devidos aos recentes esforços dos principais estudiosos da história do Atlântico e da América em incorporar a África, muito embora seja preciso reconhecer que, no âmbito da ênfase, há limitações. BLACKBURN, Robin. The making of New World slavery: From the Baroque to the Modern. Londres, Nova York: Verso, 1996. O autor traça elegantemente as contribuições da escravidão à formação da modernidade na Europa e nas suas dependências americanas, mas não explora as premissas não modernas dos africanos, ou dos americanos nativos, envolvidos neste processo. Num volume mais antigo de suas magníficas séries, Blackburn centra-se na revolução da emancipação tal como os escravos fizeram-na, mas quase exclusivamente nos aspectos modernistas destas lutas durante e depois da revolta norte-americana (BLACKBURN, Robin. The overthrow of colonial slavery, 1776-1848. Londres: Verso, 1988). 
meio das quais poderíamos construir uma visão inclusiva e balanceada do novo, dos processos formativos, das contribuições africanas para a formação do Brasil ou, de fato, de qualquer outra parte das Américas?

Começaríamos por compreender como os africanos pensavam a si próprios em múltiplos níveis. Somente no mais geral, eles reconheceram tendências que contrastavam com os hábitos manifestos dos europeus de forma a distinguirem-se deles. Os africanos que chegavam ao Brasil, portanto, relacionavam-se instintivamente uns com os outros somente em graus limitados por meio de sensibilidades partilhadas. Não é exagerado supor que quanto mais óbvias as características descritas pelos europeus - que unificam todos como "africanos" e os diferenciam dos europeus, mais transparentes se tornam e menos sentido as mesmas parecem ter aos olhos dos africanos; nas Américas, "raça" se tornaria (somente mais tarde) um fator no qual residiria a base dos olhares dos proprietários de escravos.

Ao mesmo tempo, os africanos dos séculos XVI e XVII e os portugueses que estavam no Brasil eram mais semelhantes uns aos outros do que se tornaram seus descendentes modernos; em outros termos, diferenciavam-se de outras maneiras, depreciadas pela maioria das "escolas" que projetam diferenças racializadas da modernidade para tempos anteriores à sua invenção. ${ }^{8}$ Os portugueses e seus descendentes nascidos brasileiros participaram significativamente menos que os ingleses, os holandeses e os franceses das correntes de pensamento que, no curso do século XVIII, os tornaram distintamente "modernos", no senso individualista, cívico e da "liberdade" política para os indivíduos."

Não obstante, os hábitos comerciais dos portugueses - o individualismo, o universalismo do cristianismo católico e a moldura legal e política baseada em

${ }^{8}$ Como John K. Thornton enfatizou para a Europa antes do século XVIII, em THORNTON, John K. Africa and Africans in the making of the Atlantic world, 1500-1680. $2^{\mathrm{a}}$ ed. estendida. Nova York: Cambridge University Press, 1998. [Nota de tradução: A África e os africanos na formação do mundo atlântico. Tradução de Marisa Rocha Motta. Rio de Janeiro: Editora Campus, 2004.] No entanto, os europeus e os africanos modernos têm menos diferenças do que aquelas construídas pelas ideologias raciais dos séculos XIX e XX.

9 Obviamente, Orlando Patterson se esforça para problematizar, embora nem todos os seus argumentos específicos contribuam para a formulação de minhas questões neste capítulo. Cf. PATTERSON, Orlando. Freedom in the making of Western culture. Nova York: Basic Books, 1991. Para minhas primeiras assertivas sobre a "liberdade" como ideologia da modernidade, ver: MILLER, Joseph C. Freedom. In: FINKELMAN, Paul e MILLER, Joseph C. (ed.). Macmillan Encyclopedia of World Slavery. Nova York: Macmillan/Scribner's, 1998, vol. 1, p. 344-46; e Idem. Stratégies de la marginalité: Une approche historique de l'utilisation des êtres humains et des idéologues de l'esclavage: Progéniture, piété, production personelle et prestige — Produits et profits des propriétaires. SEMINÁRIO INTERNACIONAL "OS FUNDAMENTOS IDEOLÓGICOS E JURÍDICOS DA ESCRAVATURA E DO TRÁFICO NEGREIRO”. Lisboa, Portugal, 9-10 de dezembro de 1998, Atas. Paris: Unesco Editions, 2002, p. 105-60. 
modos educados de pensamento e expressão - mantiveram-nos separados, como incipientemente "europeus" modernos, da maioria dos africanos que chegavam ao Brasil. ${ }^{10}$ No entanto, todas as diferenças são relativas e as pessoas se agruparam em torno de critérios bastante seletivos que percebiam como distintivos entre os que abraçaram como semelhantes e os que rejeitaram como estrangeiros, de acordo com o contexto no qual eles encontravam uns aos outros. A escravização dos africanos, a temporária incapacidade cultural imposta pela realocação no estranho novo mundo do Brasil e os medos e ressentimentos pertinentes aos dois lados da relação de escravização ampliaram essas distinções marginais para contrastes dicotômicos que vieram a dominar as ideologias e as identidades nas duas comunidades.

No momento em que os africanos eram jogados coletivamente na escravidão, eles se distinguiam uns dos outros - com não menos intensidade - em função do grande e flexível número de comunidades relativamente autossuficientes nas quais haviam crescido, identificadas à primeira instância por "marcas da terra" e outros símbolos de vestimentas e comportamentos pelos quais se afirmavam no pequeno grupo com o qual mantinham vínculos fortes. Identificaram-se por meio dessas afiliações familiares. Essas coletividades eram agrupamentos flexíveis que criaram, quase sempre por experiências intensas de laços pessoais, para perseguir estratégias variadas, desde laços afetivos primários até a colaboração econômica, reprodução social, a formação de clientelas pessoais, facções políticas ou - para os mulçumanos - afiliação em comunidades de culto baseadas na fé. Elas eram tão voluntárias e espontâneas quanto determinadas por descendência.

As pessoas pensavam a si mesmas diferentemente em cada uma das numerosas esferas às quais se engajavam em suas vidas diárias, nomeando-se situacionalmente em cada uma delas. Uma vez que poucas dessas múltiplas associações eram mutuamente excludentes, as pessoas na África reivindicavam tantas diferentes conexões quantas as que fossem permitidas por seus interesses. Quanto mais

\footnotetext{
${ }^{10}$ As exceções foram alguns - embora nem todos - muçulmanos da África Ocidental. REIS, João José. Slave rebellion in Brazil: The Muslin uprising of 1835 in Bahia. Edição revista e aumentada. Baltimore: John Hopkins University Press, 1993. [Nota de tradução: Rebelião escrava no Brasil: A história do levante dos malês em 1835. $2^{\mathrm{a}}$ edição revista. São Paulo: Companhia das Letras, 2003]; LOVEJOY, Paul E. Background to rebellion: The origins of muslim slaves in Bahia. In: LOVEJOY, Paul E. e ROGERS, Nicholas. Unfree labour in the development of the Atlantic world. Londres: Frank Cass, 1994, p. 151-82; e LOVEJOY, Paul E. Cerner les identités au sein de la Diaspora africaine: 1'Islam et l'esclavage aux Amériques. Tradução de Raphaëlle Masseaut. Cahiers des Anneaux de la Mémoire 1, 1999, p. 249-77.

${ }^{11}$ Foi em torno das escarificações corporais, símbolo de identidades na África, que Michael A. Gomez construiu sua intrigante história dos africanos na América do Norte. GOMEZ, Michael A. Exchanging our country marks: The transformation of African identities in the colonial and Antebellum south. Chapell Hill: University of North Carolina, 1998.
} 
afiliações, maior a autonomia pessoal e o progresso que eles poderiam alcançar manipulando as lealdades exigidas em cada uma delas contra os desafios e os constrangimentos impostos por outros. Os homens, mais que as mulheres, possuíam esses tipos de laços, e os adultos mais do que as crianças. O poder dos homens velhos decorria de uma vida inteira na construção de uma gama de conexões.

$\mathrm{Na}$ África, portanto, as pessoas lutavam para definirem a si próprias por meio de múltiplas vias de pertencimento, através da diversidade de associações que pudessem criar. Suas estratégias eram o exato oposto de uma etnicidade determinada, unívoca, unidimensional, homogênea, abrangente e estável que subjaz na maioria das discussões existentes sobre as identidades africanas no Velho ou no Novo Mundo - ou na versão colonial desta ideia sem sentido. A historicização de estereótipos da África Ocidental como "igbo"12 e "ioruba"13 deveria se estender também para as categorias étnicas convencionais da África Central como "bantu", "congo", "angola" e "benguelas", existentes no Brasil e em todas as Américas. ${ }^{14}$

Para evocar um exemplo único, digno de ser observado, pois se tornou um clichê difundido na literatura sobre "culturas africanas" nas Américas, "congo" significava uma coisa em Lima ou em São Tomé do século XVI, uma outra em Cartagena nos inícios do século XVII, e outra no Rio de Janeiro ou em São Domingos do final do séc. XVIII; ainda outra em New Orleans no início do século XIX, e algo diferente em Cuba por volta de 1850. Essas diferenças decorrem, em parte, do fato de que as pessoas das costas e das áreas adjacentes da foz do rio Zaire, que os linguistas modernos classificaram como falantes de "kikongo", se encontraram em contextos amplamente variáveis nas Américas, tanto em termos de estereótipos étnicos sob os quais foram comprados e rotulados pelos seus senhores, quanto nos níveis de diferenças que reconheciam entre eles mesmos e os outros africanos que os precederam nas populações escravizadas às quais se juntaram.

Mas as diferenças entre "congos" nas Américas derivaram mais dos diversos significados de "kongo" na África. O termo foi inicialmente usado pelos senhores da monarquia cristã do Mani Kongo que lutaram para consolidar seu

${ }^{12}$ NORTHRUP, David. Igbo and Myth Igbo: Culture and ethnicity in the Atlantic world, 1600-1850. Slavery and Abolition 21, no 3, 2000, p. 1-20.

${ }^{13}$ Por exemplo, LAW, Robin. Ethnicity and the slave trade: "Lucumi" and "Nago" as ethnonyms in West Africa. History in Africa 24, 1997, p. 205-19; MATORY, J. Lorand. The English professors of Brazil: On the diasporic roots of the Yorùbá nation. Comparative Studies in Society and History $41, \mathrm{n}^{\mathrm{o}} 1,1999$, p. $72-103$.

${ }^{14}$ MILLER. Central Africa during the era of the slave trade, op. cit. 
poder numa parte da região no século XVI. ${ }^{15}$ As várias e posteriores redes de mercadores europeus, especializados em portos diferentes ao longo da costa que ia, ao norte, de muito próximo ao Equador até Luanda, no sul, eram grupos genericamente designados como "congo", falantes do kikongo, mas que vinham de locais específicos, distantes do "reino" do Kongo, e igualmente distantes uns dos outros. Na África, a abstração etno-linguística de "kongo" pede especificações das múltiplas, menores e mutáveis identidades sociais das pessoas que ela envolve em um rótulo menos evidente para eles do que para os estrangeiros, ao menos antes do século XX.

"Etnicidade" na África, então, provê somente a mais limitada e falaciosa aproximação de uma série de identidades fluidas e criativas que as pessoas construíram para recompor os laços rompidos pela sua escravização. O conceito não tem o sentido consistente que os estudiosos atribuíram-lhe para seus propósitos, apesar de que a maioria toma os mais variados níveis de comunidades linguísticas como evidências sobre quaisquer grupos que pudessem, na prática, identificar. ${ }^{16}$ Também, uma vez que os africanos declararam-se - e, em essência, "fizeram suas histórias" - por meio do agrupamento de coletividades, eles constantemente criaram novos grupos, dos mais flexíveis e dinâmicos tipos, e usaram a escravização como o principal meio para fazê-los.

Em grande parte da África Ocidental somente poucas dessas coletividades conformaram algo próximo a fronteiras linguísticas e a maioria das pessoas falava várias línguas com o propósito de efetivamente operar nas economias complexas e nas sociedades plurais nas quais viveram. Em partes da África Central, mas de forma alguma em todo lugar, as similaridades linguísticas assumiram maior proeminência como marcadoras de identidades coletivas ${ }^{17}$ - apesar de nunca

${ }^{15}$ Ver os vários trabalhos de John Thornton que enfatizam a cristianização do Kongo. No sentido no qual eu entendo o processo político nesta região, "congo" é redundante do termo cristão. Não deveria ficar despercebido, como geralmente é, que a religião se dissipou juntamente com a monarquia no século XIX. Eu pressinto que não há outra unidade entre os vários grupos que se definem e se redefinem nesta área ao longo da história da escravidão e do tráfico de escravos.

${ }^{16}$ Considerando a miscelânea linguística de dialetos, linguagens, grupos de linguagem, em vários níveis, dos mais próximos às grandes famílias, é que os estudiosos se apropriaram disso como evidência de uniformização. De forma análoga, os níveis de diferença entre as línguas indoeuropeias - que, obviamente, dividem em alguns contextos, mas unem em outros - incluiria o português do Brasil e o peninsular, o português e o espanhol, os países de língua romana da comunidade europeia, as línguas da Europa Ocidental em relação às línguas eslavas, e daí por diante.

${ }^{17}$ Procurei apresentar a "etnicidade" angolana nestes termos historicizados em MILLER, Joseph C. Worlds apart: Africans' encounters and Africa's encounters with the Atlantic in Angola, before 1800. In: SEMINÁRIO “ENCONTRO DE POVOS E CULTURAS EM ANGOLA”. Atas. Lisboa: Instituto de Investigação Científica Tropical, 1997, p. 227-80. Ver também meu comentário geral 
excludentes e mesmo dominantes. Então, na África, apesar das muitas comunidades definidas linguisticamente persistirem por longos períodos, os hábitos linguísticos das pessoas que os preservaram evoluíram constantemente conforme foram lutando também para se identificar por outros critérios e falarem de novas maneiras, enquanto refletiam sobre os resultados dessas disputas.

\section{Processos de formação identitária no Brasil - maiorias africanas}

Em um ambiente de associações tão próximas e múltiplas, a escravidão privou as pessoas dos laços sociais que involuntariamente as protegiam do abandono daqueles que, de outra forma, seriam responsáveis por elas, através do rompimento das comunidades que escapavam da seca, das doenças, dos ataques, ou por meio da captura violenta por estranhos. Mulheres e particularmente crianças, que possuíam em menor grau essas identidades sociais, eram mais vulneráveis a tal isolamento do que os homens adultos com conexões múltiplas e mais fortes.

A individualidade, que o pensamento moderno celebra como "liberdade" pessoal, era vivida pelos africanos como uma perda debilitante, e a escravização reduziu a multiplicidade de conexões buscadas à dependência única e infantilizada a um senhor. Quaisquer que fossem os propósitos - de humilhação ou favorecimento - que os novos senhores tivessem em relação aos dependentes que haviam adquirido, os africanos responderam à escravização mobilizando habilidades de

sobre etnicidade em MILLER, Joseph C. History and Africa/ Africa and history, op. cit., p. 16-17. Essas limitações africanas no uso da "etnicidade" precedem as considerações que foram estruturadas recentemente nas animadas discussões sobre "creolização" e outros aspectos das identificações dos escravos (e dos modernos africanos americanos) com "raízes" na África. As vertentes históricas disputam os graus nos quais os africanos escravizados poderiam ter preservado sua africanidade (em posições oponentes: Mintz/Price/Morgan versus Hall/Chambers), mas problematizam o que poderia ter composto essa "africanidade" somente em termos de distinções étnicas convencionais, por exemplo, se termos americanos como "calabar" ou "congo" se referiam a grupos étnicos africanos ou a portos pelos quais os escravos passaram. A tendência da política afro-americana de explorar intensamente sua identificação com a África, para além do afrocentrismo, girava em torno das séries PBS de Henry Gates em "Wonders of the African world" e, mais recentemente, da celebrada recepção dada às informações da base de dados de Gwendolyn Midlo Hall sobre os escravos da Louisiana como uma fonte genealógica. Para entender o vídeo de Gates, é preciso ler o volume que o acompanha, GATES, Henry. Wonders of the African world. Nova York: Knopf, 1999; para a discussão, ver também o conjunto de críticas no número especial do periódico West Africa Review <www.westafricareview.com>; também resenhado em AHA Perspectives 38, $\mathrm{n}^{\circ}$ 5, 2000, p. 50-53. Para Gwendolyn Midlo Hall, ver HALL, Gwendolyn Midlo. Databases for the study of afro-Louisiana history and genealogy, 1699-1860. Baton Rouge: Louisiana State University Press, 1999; e a publicidade feita na mídia. Essas preocupações também estruturam a discussão na recente conferência CROSSING BOUNDARIES. Nova York University, 20-23 de setembro de 2000. 
sobrevivência social, aprendidas quando crianças, para recomeçar suas infinitas buscas por conexões em ambientes desconhecidos. ${ }^{18}$

A escravidão foi dilacerante e incapacitante, e a escravização, por meio da violência, poderia ser fisicamente danosa e até mesmo mortal; mas não foi a privação absoluta, inimaginável e irremediável, como quis uma visão marcada pela noção da identidade individual dependente das proteções civis modernas. Isso equivale dizer que os africanos adultos que chegaram ao Brasil através das conexões escravizantes transatlânticas ficaram debilitados fisicamente, foram submetidos a brutais abusos físicos, mas possuíam um grau de preparação espiritual para contrapor às perdas de identidades comunitárias causadas pela escravização por meio da busca de novas identidades sociais primárias. ${ }^{19}$

$\mathrm{O}$ ambiente social em que se inseriram no Brasil durante seus anos formadores, como em todas as regiões das Américas, foi um local de disputas e de múltiplos encontros entre estranhos, um momento constitutivo que desafiou as identidades conhecidas, não importando quão flexíveis e múltiplas, e intensificou diferenciações latentes à medida que as pessoas descobriam quem pensavam que fossem em reação a quem encontravam e, portanto, frequentemente produziram angustiantes confrontações em níveis não previstos e não elementares de suas identidades. ${ }^{20}$ A compulsão, ou mesmo o desespero para se redefinirem individual e coletivamente em relação aos "outros estrangeiros" foi tão intensa para os africanos como para os imigrantes vindos da Europa, ou para os ameríndios. Durante os sucessivos séculos de conexões escravizantes no Brasil, a dinâmica desses encontros evoluiu desta maneira amorfa para identidades crescentemente

${ }^{18}$ Levantaram-se questões básicas e, ao mesmo tempo, periféricas, em torno das várias tentativas de entender a escravidão na África. Duas posições contrastantes são as de: MIERS, Suzanne e KOPYTOFF, Igor (eds.). Slavery in Africa: Historical and anthropological perspectives. Madison: University of Wisconsin Press, 1977, e MEILLASSOUX, Claude. The anthropology of slavery: The womb of iron and gold. Tradução de Alide Dasnois, prefácio de Paul Lovejoy. Chicago: University of Chicago Press, 1991. Ver também LOVEJOY, Paul. Transformations in slavery: A history of slavery in Africa. $2^{\mathrm{a}}$ ed. Cambridge: Cambridge University Press, 2000 [1983] [Nota de tradução: A escravidão na África: Uma história de suas transformações. Tradução de Regina A. R. F. Beheribg e Luiz Guilherme B. Chaves. Rio de Janeiro: Civilização Brasileira, 2002].

${ }^{19}$ Por conseguinte, a tendência em várias partes do continente de distinguir, com terminologias diferenciadas, os escravos adquiridos com o intuito de integração dos outros tomados somente temporariamente para futura transferência. Notam-se também as repetidas transferências que marcaram as trajetórias de escravos que eventualmente chegaram às Américas, cujas experiências foram narradas por escrito; comparativamente, temos poucas narrativas dos descendentes desses escravizados, que poderiam revelar movimentos menores.

${ }^{20}$ BLACKBURN. Making of New World slavery, identifica de forma similar nós formativos no contexto das plantações altamente capitalizadas no Caribe (em grande parte, britânico), mas os critérios aqui são mais demográficos do que econômicos. 
definidas, principalmente privadas e, refletindo as circunstâncias que mudavam tanto na África quanto nas Américas, para as identidades brasileiras públicas e politizadas do século XIX. ${ }^{21}$

Os africanos que se redefiniram na provação da escravidão brasileira fizeramno também de acordo com os vários contextos demográficos nos quais as conexões escravizantes os colocaram, contrastando as múltiplas e flexíveis identidades africanas que trouxeram consigo com as identidades crescentemente rígidas e racializadas de "europeus" e "africanos" construídas a partir das confrontações do Novo Mundo. Selecionaram, ou descobriram, aspectos de suas origens capazes de mobilizar respostas coletivas aos desafios imediatos, de acordo com sua procedência africana, do quando, do onde, e junto a que tipo de pessoas eles foram jogados. ${ }^{22}$

O ponto de partida, e condição sine qua non, era estarem em número suficiente para organizar comunidades a partir de características comuns por eles reconhecidas. Mas a motivação para se reconhecerem uns aos outros, de uma forma em detrimento de outra, os símbolos específicos aos quais eles se ajustaram, os propósitos pelos quais "homens de nação", ou "companheiros" ou "irmãos" abraçaram-se uns aos outros na evocação de elementos culturais, surgiram das circunstâncias específicas que os provocaram.

No tempo em que os amplos modelos atlânticos da escravização e os processos gerais da formação da sociedade brasileira trouxeram grandes comunidades de africanos para o Brasil, colocando-os em contextos em que reconheciam a necessidade, ou a oportunidade, de confrontarem-se uns com os outros - ou com seus senhores, ou ainda com portugueses, brasileiros ou nativos americanos - por meio da definição coletiva, suas origens ofereceram somente uma entre a gama mais ampla de opções adquiridas nas suas experiências recentes e esmagadoras. Experiências que compartilharam ao longo das rotas que traziam cativos de regiões remotas do interior para a costa, durante os episódios de integração

${ }^{21}$ Estou, portanto, partindo do sentido dado por Gomez sobre as formas pelas quais os afrodescendentes norte-americanos trocaram as country marks [cortes na pele como marcas de identidades africanas] de seus pais por uma complexa distinção racial que emergiu nos Estados Unidos do século XIX, na medida em que eles cresceram; no entanto, eu concebo as identidades africanas em termos mais complexos e flexíveis do que os que foram desenvolvidos por Gomez.

${ }^{22}$ A literatura sobre a escravidão fez pouco uso da literatura sociológica sobre os grupos de estrangeiros forçados a viver juntos, sob severos constrangimentos: refugiados, imigrantes empobrecidos e egressos das prisões. Em todos estes casos, as gangs no estilo mafioso provêm de estruturas no interior das comunidades que vivem em grande parte fora dos moldes das sociedades estabelecidas e exploram sua vulnerabilidade da mesma forma que as organizam. Em alguns dos contextos de plantations e na maioria das situações da escravidão urbana, incluindo as do Brasil, um número suficientemente grande de escravos congregados para além da supervisão direta de seus donos buscou criar espaços para associações voluntárias deste tipo. 
parcial em comunidades estranhas nos caminhos da África, detidos em barracões costeiros onde os mercadores mantinham-nos enquanto aguardavam embarque, nas travessias da Passagem do Meio, bem como nos contatos formados no Brasil e na sucessão de transferências entre proprietários que marcavam as vidas da maioria dos sobreviventes. Como escravos eles não experimentaram um único rompimento de sua origem, segura, única e estável na África, mas, ao contrário, uma série de transferências e integrações parciais e efêmeras, todas quebradas novamente por sua vulnerabilidade aos deslocamentos.

O modo pelo qual estes sobreviventes da escravização subsequentemente pensavam a si mesmos em termos das vidas que eles haviam criado antes de sua captura e exílio dependeu tanto do valor que tinham para seus donos na América, quanto de quem eles haviam sido na África. Para além da etnicidade baseada na língua, eles tiveram enfatizadas outras características, algumas vezes primárias, como as de grupos etários, de gênero, habilidades profissionais e experiências, distinções doutrinárias entre mulçumanos, e posição social. As circunstâncias específicas que encontraram no Novo Mundo poderiam ter transformado esses agrupamentos potenciais em qualquer outra identidade como base para a formação de novas conexões com seus senhores, por meio de características que os tornassem valiosos como empregados. Conhecimentos no manuseio de gado, técnicas de agricultura, metalurgia, outras habilidades artesanais e de caça eram atributos pelos quais os senhores reconheciam a propriedade humana que haviam adquirido por seu valor comercial.

Por outro lado, grupos de recém-chegados uniam-se em torno de seus predecessores para estabelecer posições no interior das comunidades de escravos já existentes. A predominância de homens jovens entre os africanos recém-chegados poderia ter criado uma tendência de ocasionar rituais para meninos adolescentes, a forma principal de cerimônia pública que os jovens teriam vivenciado na África na tenra idade em que foram capturados, e em treinamentos militares que os adolescentes mais velhos poderiam ter adquirido. ${ }^{23}$ Entre os escravos, os conhecimentos na arte da cura tinham um interesse especial. Mas a criação da

${ }^{23}$ Para a principal forma de experiência que John Thornton identificou numa série de cuidadosas investigações sobre as circunstâncias especificamente africanas a partir das quais determinados grupos afirmam-se abertamente nas Américas, ver seus artigos: THORNTON, John. African dimensions of the Stono Rebellion. American Historical Review 96, n 4, 1991, p. 1.101-13; African soldiers in the Haitian Revolution. Journal of Caribbean History 25, n 1-2, 1991, p. 58-80; e "I am the subject of the king of Congo": African political ideology and the Haitian Revolution. Journal of World History 4, n² 2, 1993, p. 181-214. Todos sistematizados por THORNTON, John. Warfare in Atlantic Africa, 1500-1800. Nova York: Cambridge University Press, 1999. 
comunidade dependia de conter o sentido maléfico que o rompimento esmagador indicava e que via a sua escravização em África como bruxaria, uma vez que eles interpretavam o isolamento involuntário como uma quebra da integridade da comunidade, possível somente por meio de violações vindas de dentro (do seio da comunidade) e, portanto, como traição de alguém pertencente à esfera da confiança. De forma similar, compreendiam o isolamento da escravidão como vulnerabilidade a predadores estrangeiros - não somente os captores europeus, a quem inicialmente viam como canibais, mas também os africanos de outras procedências com quem caíram em armadilha nas Américas. ${ }^{24}$

Sem pesquisar a interpretação que os escravos faziam de sua escravidão como bruxaria, pode-se somente especular sobre as suspeitas que tinham um em relação ao outro, o terror e os obstáculos em formarem laços efetivos durante a Passagem do Meio. ${ }^{25}$ Era uma contradição de proporções agoniadas o fato de suspeitarem dos estranhos a quem teriam que recorrer em busca de sua própria salvação. Em casa, tentaram extirpar a maldade quintessencial por meio de "movimentos de erradicação", cultos de cura que reagruparam comunidades desintegradas na direção de um intenso espírito de unidade coletiva. Face ao rompimento da

${ }^{24}$ A feitiçaria, como a metáfora por meio da qual os africanos experimentaram a era da escravização, só recentemente começou a receber investigações sistemáticas como requer o tema. Ver: MILLER. Way of death, op. cit., para um vislumbre inicial do tráfico tal como era visto pelos escravizados em Angola; também GOMEZ. Exchanging our country marks, op. cit. e SHAW, Rosalind. The production of Witchcraft/Witchcraft as production: Memory, modernity and the slave trade in Sierra Leone. American Ethnologist 24, nº 4, 1997, p. 856-67. Elizabeth Isichei explorou a consciência popular da escravidão (e outros aspectos da modernidade) em: ISICHEI, Elizabeth. Cowries, statues and zombis: Some African representations of wealth and death from the sea, texto não publicado, apresentado na conferência THE ATLANTIC SLAVE TRADE IN AFRICAN AND AFRICAN-AMERICAN MEMORY. Anais.University of Chicago, 23-25 de maio de 1997. Ver também ISICHEI, Elizabeth. Voices of the African poor. Rochester: University of Rochester Press, 2002.

${ }^{25}$ As indicações do terror são abundantes nos estudos citados na nota precedente, incluindo as imagens dos europeus como canibais (semelhantes a bruxos), bem como o conhecido susto que os africanos sentiam quando, depois de capturados, vislumbravam os caldeirões de cobre mantidos nos convés dos navios que os transportariam. Ver o promissor, ambicioso e sugestivo trabalho de SWEET, James H. Recreating Africa: Race, religion, and sexuality in the African-Portuguese world, 1441-1770. Dissertação de PhD. City University of New York, 1999 [Nota de tradução: Recriar África: Cultura, parentesco e religião no mundo afro-português. Tradução de João Reis Nunes. Lisboa: Edições 70, 2007], que investiga este e outros aspectos íntimos das vidas dos africanos sob a escravidão que podem colocar em cena uma ampla agenda de temas para futuras investigações. Para resultados preliminares, ver SWEET, James H. Male homosexuality and spiritism in the African diaspora: The legacies of a link. Journal of the History of Sexuality $7, \mathrm{n}^{\circ}$ 2, 1996, p. 184-202; e Recreating Africa: Mbundu "Calundu" rituals and Portuguese response in seventeenth-century Brazil. Texto não publicado apresentado no FORUM ON EUROPEAN EXPANSION AND GLOBAL INTERACTION - Third Biennial Meeting, St. Augustine, Florida, 1719 de fevereiro de 2000. Ver também TAYLOR, Eric. If we must die: A history of shipboard insurrections during the slave trade. Dissertação de Ph.D., University of California - Los Angeles, 2000. 
crença social, da vulnerabilidade implícita ao desenraizamento e às sucessivas transferências, os africanos poderiam ter se unido em torno de qualquer estratégia de cura ou de alívio que identificassem como promissora. Uma vez que a eficácia antecipada desses antídotos para as aflições reais da imaginação (em oposição às aflições imaginadas) dependeu da promessa de renovação, da esperança no não experimentado (e, portanto, ainda não desacreditado), as gerações precedentes de cativos devem ter olhado para os recém-chegados, particularmente os vindos de regiões estranhas para eles, como possibilidades de cura para seu infortúnio.

Portanto, os africanos teriam entendido as religiões europeias, especialmente o cristianismo, como forma de cura para as doenças sociais que os afligiam como as promessas da igreja de salvação das tentações do demônio vistas como o equivalente aos movimentos antibruxaria que eles conheciam na África. Eles podem ter combinado, no Brasil, uma devoção sincera ao catolicismo com maneiras próprias de combater o isolamento da escravidão, cobrindo as estratégias subjacentes com respeitáveis metáforas católicas, tanto quanto protegendo quaisquer potenciais possibilidades de reintegração social e pessoal em termos mundanos. Eles podiam esconder as suas forças espirituais da perversão dos seus senhores que intencionavam mais dividi-los que uni-los. ${ }^{26}$

No início do século XIX, em algumas áreas, populações não mulçumanas abraçaram o Islã por seus reputados poderes terapêuticos. Isso evidenciaria a eficácia das estratégias comunitárias e familiares dos escravos para a cura de agonias pessoais e sociais trazidas pelo isolamento, cujo significado era tão pouco reconhecido pelos seus senhores. A partir disso, nos registros senhoriais, podemse encontrar somente pistas oblíquas de sua existência. No entanto, sua relativa invisibilidade na historiografia sobre a escravidão no Brasil deriva igualmente, ou mais, da incapacidade dos historiadores em considerar o que pode ser inferido

${ }^{26}$ Outro aspecto não investigado das experiências dos escravos diante sua escravização é a resignação que os africanos trouxeram de sua origem - muçulmana ou outra - que enfatiza a aceitação e as virtudes do clientelismo em relação a patrões responsáveis. Assertivas inspiradas por um senso moderno dos direitos individuais provavelmente não teriam ocorrido entre pessoas que pensam nos termos que James C. Scott explorou (SCOTT, James C. Weapons of the weak. Everyday forms of peasant resistance. New Haven: Yale University Press, 1985), utilizado por pessoas humildes que agem, positivamente e de forma eficaz, em meios privados, aparecendo nas esferas públicas da política somente quando autoridades de inquestionável legitimidade falham em encontrar suas responsabilidades numa aceitável economia moral do camponês (SCOTT, James C. The moral economy of the peasant. Rebellion and subsistence in Southeast Asia. New Haven: Yale University Press, 1976). Tais premissas soam plausíveis para as rebeliões africanas nas Américas contra os abusos pessoais da escravidão que previam tanto a vitória como a continuação da escravidão de outros. 
a partir das origens dos escravos na África e da experiência específica do seu desenraizamento na avaliação das reações das maiorias escravizadas do Brasil.

\section{As linhas gerais das identidades possíveis na história dos africanos no Brasil - anos formativos}

Os primeiros africanos a chegarem ao Brasil no século XVI vieram em número muito pequeno para suscitar neles qualquer interesse em se definirem como uma comunidade em oposição aos seus senhores europeus. ${ }^{27}$ No início do século, os centro-africanos foram agrupados nas plantações de açúcar emergentes em São Tomé. Inicialmente, através dos canais do Congo cristão que os identificaram como "congo", e depois através de redes comerciais competitivas, localizadas ao longo do Baixo Kwanza, e trazidos em excursões militares, capturados por forças comandadas por senhores de guerra conhecidos como ngola, e a partir daí identificados como "angolares". Essas identidades estabeleceram os termos iniciais pelos quais os portugueses posteriormente reconheceram seus sucessores no Brasil. Tais identificações dos escravos em termos dos lugares onde haviam sido adquiridos, ou de quem os havia vendido, como distintas das identidades radicalmente diferentes que os escravos africanos poderiam ter abraçado, refletem apuradamente os termos comerciais pelos quais os europeus reconheceram os estrangeiros a quem, por toda a história da escravidão no Atlântico, pensavam somente como propriedade.

Naquela época, no entanto, no nordeste do Brasil, os portugueses contavam, principalmente, com o trabalho de gangs ameríndias e não tanto dos africanos. Estes só cresceram gradualmente de forma competitiva a partir de outros mercados mais ricos e mais acessíveis a mão de obra mais custosa do litoral africano, na Ibéria do século XVI e, particularmente, nas cidades das províncias de mineração de prata da América espanhola continental.

A julgar pelas referências oblíquas a africanos nos registros dessa fase inicial das conexões escravizantes no Brasil, e que são de fato inferíveis com alguma segurança por sua própria obliquidade, os primeiros africanos trazidos como escravos vieram em pequenos números, principalmente da área da Alta Guiné, na África Ocidental, muitos deles via Portugal, e eram empregados em posições qualificadas e serviços domésticos. Na África, a primeira resposta dos indivíduos isolados era buscar um senhor benigno, um protetor pessoal que pudesse

\footnotetext{
${ }^{27}$ Muitos deles construídos nos padrões das origens africanas e das rotas atlânticas de escravização elaboradas em MILLER. Central Africa during the era of the slave trade, op. cit.
} 
assumir responsabilidade por garantias, múltiplas e comunais, do bem-estar pessoal que haviam perdido. Essas pessoas teriam se identificado de forma mais próxima com seus senhores - mais no sentido de aprendiz do que de servidão em termos europeus - do que com os nativos americanos que formavam a maioria dos trabalhadores compulsórios de campos e de florestas. ${ }^{28} \mathrm{~A}$ influência destes na maneira pela qual um número maior de africanos no Brasil, posteriormente, distinguiu-se sob as condições muito diferentes da escravização de gangs foi reconhecidamente limitada.

Em algum momento, por volta da virada do século XVII, mercadores holandeses financiaram a mudança na direção de empregarem escravos em números socialmente e culturalmente viáveis como "africanos" em Pernambuco e na Bahia. ${ }^{29}$ Os locais de origem dessas pessoas na África, e mesmo seus números, permanecem obscuros, uma vez que as autoridades legais espanholas impuseram o asiento ao mercado atlântico dos portugueses durante o período da monarquia dual (União das Monarquias Ibéricas, 1580-1640), e forneceram os únicos registros dos movimentos dos navios e focalizaram os cativos levados para Vera Cruz, Cartagena e o Rio da Prata (como entradas para as regiões andinas) mais do que ao Brasil. ${ }^{30}$ No entanto, inferindo a partir dos números posteriores, anotados silenciosamente em desafio às autoridades de Lisboa, Sevilha e Amsterdã, os pernambucanos, nestes primeiros anos do século XVII, teriam concentrado o suporte comercial que obtiveram dos holandeses na produção de açúcar e teriam se aventurado independentemente pelas pequenas rotas do Atlântico para compra-

${ }^{28}$ Este padrão é recorrente nas Américas na primeira geração de escravos, nas colônias ibéricas como uma extensão dos estilos prevalecentes da escravidão doméstica no Mediterrâneo Renascentista. Ira Berlin chamou a atenção para isso de uma perspectiva inglesa (embora num grau que me parece excessivo) em: BERLIN, Ira. Many thousand gone: The first two centuries of slavery in North America. Nova York: Oxford University Press, 1998, e, especificamente, em Idem. From Creole to African: Atlantic Creoles and the origins of African American society in Mainland North America. William and Mary Quarterly 53, nº 2, 1996, p. 251-88.

${ }^{29}$ Uma leitura cuidadosa de SCHWARTZ, Stuart B. Sugar plantations and the formation of Brazilian society: Bahia, 1550-1835. Nova York: Cambridge University Press, 1986, revela a lentidão desta fase na escravidão no Brasil. Uma obscuridade ainda maior envolve os anos de formação em Pernambuco, com exceção do trabalho de PUNTONI, Pedro. A mísera sorte: a escravidão africana no Brasil holandês e as guerras do tráfico no Atlântico sul, 1621-1648. São Paulo: Hucitec, 1999. A especificidade regional das conexões escravizantes, em geral durante o tráfico de escravos, foi um dos padrões reavaliados pelas análises do banco de dados das viagens negreiras; partes particulares das Américas tendem a receber de forma consistente escravos provenientes de determinadas partes da costa africana, pelo menos em termos médios.

${ }^{30} \mathrm{O}$ comércio do asiento e sua concentração em postos controlados pelo governo em Luanda, no espaço que se transformou na conquista de Angola (o território controlado pelos portugueses) é melhor conhecido. Para um resumo deste comércio, que tem o seu pico entre 1600 e 1620, ver MILLER. Central Africa during the era of the slave trade, op. cit., nota 10. 
rem escravos eles mesmos, em postos mercantis portugueses ao longo da costa da Alta Guiné, adquirindo, portanto, a primeira geração de africanos colocados a serviço da cana-de-açúcar entre os anos de 1590 e 1620.

Nos anos de 1630, a Companhia Holandesa das Índias Ocidentais (WIC) se apoderou das capitanias açucareiras brasileiras, mas acrescentou somente um número relativamente pequeno de escravos, nos anos de 1640, a maioria advinda da África Central. ${ }^{31}$ Os conflitos daquela década que finalmente levaram os holandeses a deixar o Brasil em 1654, devem ter inibido significativamente a entrega de novos cativos da África e contribuído para desordens nas plantações que, por sua vez, permitiram o florescimento dos famosos redutos maroons tais como o Quilombo dos Palmares, nos anos de 1650 e após. ${ }^{32}$ Uma vez que um número limitado de escravos - comparados à esmagadora maioria dos novos africanos entre os escravizados daquela época no nordeste do Brasil - teve a oportunidade de formar comunidades com duração variável, as prósperas colônias isoladas da época sugerem que eles aparentemente o fizeram - em sua maioria - através de fugas não coordenadas para dentro das florestas adjacentes.

Essas colônias de refugiados, a julgar pelas recentes evidências arqueológicas sobre a última fase do Quilombo dos Palmares, eram culturalmente mistas, com contribuições significativas dos nativos americanos (índios), predecessores recentes dos africanos como trabalhadores nos campos de açúcar do nordeste brasileiro. ${ }^{33} \mathrm{O}$ termo quilombo, claro, entrou para o vocabulário brasileiro a partir do encontro de outros portugueses com bandos de guerreiros africanos nomeados dessa forma em Angola, e que os estudiosos, por longo tempo, pensaram ser

${ }^{31}$ Ver as tentativas de inferir esses números com base nas quantidades de açúcar produzidos em ELTIS, David, BEHRENDT, Stephen D. e RICHARDSON, David. A participação dos países da Europa e das Américas no tráfico transatlântico de escravos: Novas evidências. Afro-Asia 24, 2000, p. 9-50. Outra revisão recente dos valores é encontrada em ELTIS, David. The volume and structure of transatlantic slave trade: A reassessment. William and Mary Quarterly 58, n 1, 2001, p. 17-46.

${ }^{32}$ POSTMA, Johannes. The Dutch in the Atlantic slave trade 1600-1815. Nova York: Cambridge University Press, 1990; GOSLINGA, Cornelis Ch. The Dutch in the Caribbean and in the Guianas 1680-1791. Wolfeboro, N. H.: Longwood, 1985; ISRAEL, Jonathan I. The Dutch Republic: Its rise, greatness and fall, 1477-1806. Nova York: Oxford University Press, 1995.

${ }^{33}$ Os leitores perceberão a dúvida implícita que este fraseado lança sobre o lendário caráter "angolano" do "Estado" em Palmares, pelo menos no momento considerado neste ponto da argumentação; céticos poderão recordar que comunidades maroon também têm suas histórias, e que as condições da década de 1630 não anteciparam aquelas que, depois de 1650, resultaram nas maiores mudanças nas origens dos africanos que foram trazidos para o nordeste do Brasil. Até que tenhamos evidências que datem esses aspectos da história de Palmares, década por década, as conclusões baseadas em evidências posteriores devem ser aplicadas somente para os períodos subsequentes que eles esclarecem. Para uma argumentação comparável aplicada a São Tomé, ver VANSINA, Jan. Quilombos on S. Tomé, or in search of original sources. History in Africa 23, 1996, p. 453-59. 
continuidades da estrutura daquele precedente africano para as circunstâncias em Pernambuco. Os cativos angolanos que a WIC trouxe para Pernambuco nos anos 1640 forneceram candidatos óbvios a portadores da ideia, se não também das práticas a que se referem. No entanto, as conexões transatlânticas se assentam menos na transferência de um conjunto integral de práticas angolanas do que em estratégias ad hoc de congregar novas comunidades de refugiados vindos das mais diferentes origens que os desordeiros armados a serviço da escravidão haviam provocado, muito antes, em Angola.

Em meados do século XVII, as pessoas na África centro-ocidental haviam sofrido mais de um século de dispersão das comunidades construídas por laços ancestrais, ou qualquer outra forma estável. Poucos cativos retirados dos conflitos ali ocorridos não estariam familiarizados com as técnicas de agrupar refugiados em novas comunidades sob a disciplina rígida necessária para autodefesa. Nas Américas, essas comunidades incluíam índios de forma tão oportunista quanto davam boas vindas aos africanos da Alta Guiné. A terminologia pode ter sido angolana, e quilombo pode ter sido o termo empregado pelos portugueses mais do que pelos africanos, mas em Palmares ele referiu-se mais a experiências na América e menos na África.

As continuidades da África para a América ocorreram nas estratégias e técnicas desenvolvidas em resposta a experiências paralelas, neste caso as rupturas, os deslocamentos e o desenvolvimento de novas comunidades sob a coação da captura e da escravização, não nos materiais culturais específicos de que os refugiados se apropriaram, ad hoc, para realizá-los em um ou outro contexto histórico.

A heterogeneidade dos materiais culturais específicos pelos quais os fugitivos se uniram nos Palmares demonstra a qualidade integrativa necessariamente espontânea, oportunista - como bricoleur - da construção de novas identidades sob as restrições da escravidão nas Américas: pessoas desesperadas trabalharam criativamente com quaisquer ideias e símbolos que lhes chegaram às mãos, momento a momento, uma vez que tinham tão poucas oportunidades de implementar estratégias mais elaboradas. Eles deram novos significados para velhos símbolos, convertendo ideias que os diferenciaram de outros na África em símbolos que uniram pessoas totalmente estranhas na América.

No caso dos quilombos de Angola e Brasil, eles (ou os portugueses) inverteram (ou alteraram) até mesmo as relações dos africanos e europeus a quem eles designaram: em Angola, as forças militares portuguesas confiaram pesadamente nos bandos de africanos chamados imbangala (ou "jaga"), que organizaram nos campos de batalha conhecidos como quilombos, enquanto, em Pernambuco, os veteranos, que deram a Palmares os atributos africanos que Palmares exibiu, 
converteram estratégias associativas desenvolvidas em Angola para sustentar sua oposição na América. A conexão está na continuidade da superação da dispersão e do isolamento da escravização e da escravidão, não na ressurreição sistemática de uma origem africana às vidas na América, sobre a qual os escravos não tiveram nenhum controle. Continuidades em forma, portanto, tornaram-se meios de alcançar efeitos totalmente novos, tanto na África quanto na América.

Nas lavouras de Pernambuco, os plantadores portugueses enfrentaram intervalos de escassez de trabalho quando reconquistaram o controle de seus próprios negócios, expulsando os holandeses. Naquela época, o sudoeste brasileiro havia recapturado Benguela e Luanda, os dois principais portos de escravos sob a autoridade portuguesa na África central, após um período correspondente (1641-1648) de intrusão holandesa ali. A restauração da autoridade portuguesa em Luanda colocou os pernambucanos em posição de estabelecerem domínio sobre o suprimento de escravos vindos dali pelo resto do século XVII. ${ }^{34}$

Presumivelmente, durante esses anos, os participantes pernambucanos também vendiam cativos para seus conterrâneos da Bahia e para o sul, pelo menos no período imediato à restauração da autoridade portuguesa no nordeste brasileiro. Eles teriam, desse modo, dado, aos plantadores da Bahia, motivos para reduzirem sua dependência de suprimentos vitais de mão de obra de seus rivais das capitanias das vizinhanças, suplementando essas fontes angolanas com as famosas trocas dos escravos por tabaco em Uidá e outros portos ao longo do que eles ajudaram a se tornar a Costa dos Escravos na África Ocidental dos anos de 1680. Os baianos distinguiam esse africanos do ocidente, a partir do ponto em que se tornaram escravos (sua coisificação), como "minas", o nome pelo qual os portugueses conheciam toda a costa oeste do forte de São Jorge da Mina, o qual seus predecessores do século XV nas costas ocidentais do rio Volta e os ingleses conheciam como Costa do Ouro.

Os pernambucanos, então, reestocaram mão de obra escrava tanto em Pernambuco como na Bahia após 1655, especialmente com cativos vindos de Angola, muitos deles capturados em guerras angolanas daquele tempo. No Recife, podem-se encontrar as consequências letais de introdução de grande número de novas populações de africanos subnutridos e sobrecarregados de trabalho na pandemia de sarampo de 1664-1666 e novamente - mais geralmente - durante os anos 1680, quando a estiagem, tanto na África central quanto na ocidental,

${ }^{34}$ Argumento elaborado por MILLER. Way of death. Não farei referências específicas às inúmeras premissas discutidas no livro. 
espalhou epidemias que os cativos capturados nas guerras consequentes trouxeram para o Brasil por meio das conexões escravizantes, e então caíram vítimas de uma devastadora deflagração da febre amarela em $1685 .{ }^{35}$

A Bahia, mas não Pernambuco, repôs a perda dos africanos da África central com africanos minas do ocidente baiano, entre os anos 1680 e 1690, especialmente vindos de regiões do interior de Uidá, nessa época entrando no ciclo de conflito armado, característico do mercado escravagista em toda a África, que culminou ali quando os refugiados estabeleceram o estado militar de Dahomey. ${ }^{36}$ A mortalidade sofrida nesses desastres epidemiológicos pode ter sido grande o bastante para que as ondas de africanos minas do ocidente na Bahia e angolanos em Pernambuco se encontrassem em posição de recomeçar os processos de formação comunitária entre os escravos na zona rural do nordeste brasileiro. ${ }^{37}$

$\mathrm{Na}$ medida em que Recife e Salvador, os principais portos das capitanias, tinham, naquela altura, desenvolvido comunidades urbanas de escravos, eles incluíram mais sobreviventes aculturados e descendentes das primeiras gerações, tão portugueses em cultura quanto especificamente africanos. No Brasil inicial, os nativos foram introduzidos no ambiente notoriamente mortífero das plantações, no qual eles podiam manter poucas estratégias comunitárias permanentes enquanto lutavam isoladamente por meramente sobreviver fisicamente, colaborando primeiramente de modo efêmero e desestruturado. Somente os sobreviventes afortunados construíram conexões, uma vez que eles tendiam a elaborar estratégias de fazê-lo especialmente nos centros onde os cativos veteranos no Brasil congregaram-se em número suficiente para trabalhar juntos e em bases sustentadas.

A distinção entre o centro e o campo nas formas como lutaram por suas identidades, por eles próprios durante a escravidão, ou - do ponto de vista dos escravos que chegavam - entre as plantações de onde desejavam escapar e as grandes cidades portuárias na costa que eles poderiam encontrar tornou-se menos dramática nas últimas gerações, mas, no século XVIII, elas continuaram

35 ALDEN, Dauril e MILLER, Joseph C. Unwanted cargoes: The origins and dissemination of smallpox via the slave trade from Africa to Brazil, c. 1560-1830. In: KIPLE, Kenneth F. (ed.). The African exchange: Toward a biological history of the black people. Durham, N. C.: Duke University Press, 1988, p. 35-109; revisado em Out of Africa: The slave trade and the transmission of smallpox to Brazil, ca. 1560-ca. 1830. Journal of Interdisciplinary History 18, nº 2, 1987, p. 195-224.

${ }^{36}$ LAW, Robin. The slave coast of West Africa 1550-1750: The impact of the Atlantic slave trade on an African society. Londres: Oxford University Press, 1991, p. 282-85.

${ }^{37}$ Em linhas gerais, a primeira onda, entre as décadas de 1620 e 1630, foi interrompida pela conquista holandesa e as guerras de restauração do controle português sobre Pernambuco e Bahia; a segunda onda, entre as décadas de 1650 e 1660, estabelecida no controle pernambucano de Luanda; e a terceira onda de Minas foi inaugurada pelos baianos, entre as décadas de 1670 e 1680. 
significativas o suficiente para que os escravos pudessem construir identidades e comunidades, seguindo estratégias diferenciadas.

Somente no século XIX, seus sucessores recorreram a outras formas de identidade, transcendendo a divisão rural-urbano. Nessas primeiras fases da escravidão no Brasil, os significados africanos das associações de estratégias que os escravos buscaram para proteger-se, criaram novas identidades no Brasil. O apadrinhamento e os casamentos sancionados pela igreja católica haviam se tornado comuns, muito difundidos mesmo nas áreas urbanas. Para os africanos mantidos na escravidão, ambos os laços, seguramente sacramentados pela igreja, inibiram ou pelo menos tornaram vergonhoso e espiritualmente perigoso - futuras vendas ou transferências pelos proprietários cujos cativos os adotaram como protetores, ou que estivessem ligados indissoluvelmente pelo sacramento do matrimônio a escravos mantidos por seus próprios senhores - ou de outros locais.

Essas duas estratégias propagaram os usos africanos de clientela e afiliação pelo casamento para grupos dominantes que foram a base da construção de conexões e identidades. A responsabilidade pessoal da parte do senhor em não vender a criança, ou sua família, tomados sob o guarda-chuva paternalístico que os escravos asseguraram através do apadrinhamento, adaptou a distinção que os africanos observaram entre os escravos afiliados a comunidades de parentesco (consanguinidade) e os outros mantidos somente temporariamente e instrumentalmente, aguardando transferência. ${ }^{38}$ Eles pareceram, também, basear-se nas estratégias das primeiras gerações de africanos, especialmente mantidos em números relativamente pequenos em trabalhos domésticos ou especiais, alguns com origens em Portugal, que buscaram estabelecer conexões observando menos uns aos outros do que os domínios domésticos (households) e os grupos de trabalho de seus senhores.

Alguns africanos centrais também se utilizaram do catolicismo em casa para reconstruírem as comunidades rompidas pela escravidão. Muitas autoridades africanas no "reino" do Congo e em partes da Angola dominada pelos portugueses se apropriaram dos esforços missionários de conversão e batismo para consolidarem um novo estado nominalmente católico sob a proteção dos portugueses. O batismo em Luanda, durante esse processo de embarcação, conduziu outros escravos - de regiões do interior para além das ambições até mesmo dos intrépidos missionários

${ }^{38}$ Ver VANSINA, Jan. Paths in the rainforest: Toward a history of political tradition in equatorial Africa. Madison: University of Wisconsin Press, 1990, para a distinção terminológica relacionada com a propagação do comércio escravo pela África Central; a diferença foi reconhecida também em outros lugares, por exemplo, entre os Asante. Ver YARAK, Larry W. Slavery and the state in Asante history. In: The cloth of many colored silks: Papers in history and society, Ghanaian and Islamic, in honor of Ivar Wilks. Evanston, Ill.: Northwestern University Press, 1996, p. 223-40. 
do século XVII - ao Brasil, já nominalmente dentro da congregação católica, pelo menos nesses primeiros anos. Assim batizados, o que quer que tenham conhecido ou se envolvido com o catolicismo em qualquer sentido europeu, esses escravos tiraram, então, vantagem de sua elegibilidade sacramental para defender-se contra os efeitos incapacitadores das transferências adicionais, para não mencionar as perdas humanas. $\mathrm{O}$ sacramento do batismo, estendido no Brasil aos recém nascidos, reconheceu o parentesco das crianças e, portanto, estabeleceu um laço entre, pelo menos, a mãe e a criança que os senhores poderiam subsequentemente ameaçar somente com o risco de condenação pública e excomunhão eclesiástica.

Na sociedade patriarcal do Brasil católico, na qual os colonos (plantadores) e mercadores construíram domínios domésticos estendidos à família e dependentes com o suporte da igreja, o casamento, o apadrinhamento e o batismo deram aos escravos, particularmente às mulheres, a oportunidade de encontrarem um lugar de relativa segurança e, portanto, identidades para si mesmos. Visto em termos das experiências e estratégias dos escravos que buscavam a sanção da igreja, para além do mais conhecido zelo dos padres católicos para salvar as almas dos africanos pagãos (selvagens) e a tolerância da maioria dos monarcas portugueses católicos, o rito católico permitiu o nascimento de uma comunidade familiar e adicionou sua promessa de perpetuação a uma linhagem própria no futuro.

Os sacramentos católicos trouxeram estabilidade através da confirmação das relações das mulheres com seus senhores de maneira privada (particulares), enquanto que os escravos homens se apropriaram de outras formas de exploração familiar do catolicismo no Brasil, em uma esfera mais pública, aberta aos homens. As irmandades e confrarias leigas representaram - ao contrário - o esforço dos homens em prol de paróquias urbanas para desenvolverem associações entre eles mesmos, através da extensão desse tipo de identificação patriarcal e cristã para as ruas e mercados das cidades. Essas confraternidades, lideradas por predecessores assimilados, teriam emergido de uma grande congregação de novos homens escravos no nordeste, talvez no início dos anos 1650 e certamente no início do século XVIII ali e em Minas Gerais depois de 1710, uma das primeiras concentrações dos nascidos africanos - a maioria homens - no Brasil.

A extensão pela qual escravos de origens africanas reuniram-se nas diferentes irmandades e o grau de especificidades africanas com as quais eles reivindicaram as similaridades em torno das quais se uniram teriam derivado da espécie de concentrações de escravos chegando de regiões contrastantes na África. ${ }^{39}$ Eles

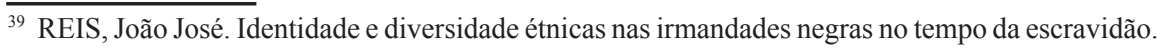


reagiram mais em termos de contrastes externos do que semelhanças internas, mais em termos de situações no Brasil do que de origens na África. Os usos das confraternidades para os escravos, de acordo com as concentrações demográficas das quais eles surgiram, guardam semelhanças com as dos cabildos da Cuba do século XIX e outras associações voluntárias de homens urbanos que novas ondas de escravos organizaram para controlar o trabalho e outras oportunidades em cidades coloniais das Américas.

Uma vez que os africanos em casa buscaram identidades derivadas da solidariedade de suas comunidades ancestrais, traçando a descendência dos vivos, ligando-os com os que já haviam ido, a afirmação última (definitiva) do "eu" veio em morrer entre seus iguais, ou reunindo-se com aqueles a quem haviam perdido pela morte.

O desenraizamento, a "morte social" da escravidão deixou os africanos integrados nessas comunidades originárias por nascimento, mas deixou-os sozinhos no Brasil, desejando por toda a vida reconquistar as conexões com suas origens para retornar para "casa" na morte. Essa crença na reunificação em "voar de volta para África", e a determinação em fazê-lo, levando alguns a tirar a própria vida em momentos de grande e desolador isolamento, é particularmente atribuída, na literatura sobre a escravidão, aos escravos de origem igbo, e reportou-se especialmente às colônias de língua inglesa. Mas as motivações subjacentes para reconquistar identidade - vitalidade social - na morte eram mais gerais e os escravos, em todos os lugares, agiram sobre isso de forma coletiva através da união em sociedades fúnebres que traduziriam a mortalidade ubíqua da escravização em triunfo final dos escravizados.

Ninguém chegou ao Brasil sem ter testemunhado a morte na mais aterrorizante proximidade, que rondava a todos na captura, no transporte para a costa e acorrentados a cadáveres durante a travessia do oceano. O isolamento e desprezo percebido pelos cativos que viram outros morrerem, escolhidos arbitrariamente e assassinados, corpos abandonados ao longo das trilhas para serem consumidos por animais, restos mortais jogados desdenhosamente próximos aos barracões, amontoados em estado de putrefação e descarregados no oceano com o mais puro desdém, devem ter deixado os sobreviventes resolvidos, senão obcecados, em converter a contínua morte no Brasil em afirmação de uma comunidade que iria reconhecê-los e relembrá-los.

Tempo: Revista do Departamento de História da Universidade Federal Fluminense, 2, nº 3, 1997 , p. 7-33. 
Alguns podem considerar as irmandades leigas como sociedades funerárias que ofereceram uma perspectiva de vida eterna em termos que vão além daqueles que os portugueses entendiam como sendo o paraíso católico, e como as predecessoras da mais pagã e abertamente africana das associações, que até mesmo pequenos grupos de escravos formaram a partir de uma origem suficientemente similar para compartilharem meios coletivos de se integrarem nas comunidades da morte. Em Luanda, um oceano mais próximo às raízes africanas daqueles escravizados, tanto quanto em uma cidade de escravos em qualquer cidade no Brasil, descrições perturbadoras de enormes encontros funerários barulhentos (entame/entambe), aparecem com uma frequência que deve indicar a preocupação da população urbana com a morte penetrante, e a resposta a sua presença através da afirmação coletiva de identidade com os mortos.

O mesmo povo estabelecido na escravidão do Brasil deve ter se associado a outros para recuperar na morte a identidade pessoal perdida pelos vivos. O impulso restaurador deve ter dominado os homens, para quem a escravidão negou qualquer perspectiva futura de levarem suas vidas na presença da sua progenitura, enquanto que as mulheres devem ter usado os ritos católicos do casamento e batismo para moderar sua própria mortalidade em locais então reclamados para suas crianças.

Os sacramentos católicos restauraram a esperança de uma segurança pessoal, na morte tanto quanto em vida, numa espécie de reparação ao que a escravização causou às suas vítimas. Refletindo uma época de solidariedade religiosa europeia que estava de fato se dissipando entre a competitividade e as prioridades individualistas da economia do comércio atlântico, eles devem ter atraído os africanos que chegavam, oferecendo apoio, proteção responsável do tipo que os escravizados poderiam ter buscado na África. Mas a corrupção da escravidão comercial na qual se encontraram, tanto na África quanto no Brasil, fundamentava-se nas exigências do crédito financeiro, mais do que no credito pessoal que subjaz às conexões escravagistas e podia, a qualquer tempo, forçar os senhores e senhoras em potencial a salvarem-se da falência impeditiva através do sacrifício dos laços sociais nascentes entre os escravos, exercendo seus direitos de proprietários para vendê-los, destruindo então, novamente, qualquer florescimento de identidade que pudesse ter desabrochado dentro da escravidão. A "confiança” manteve, no sentido inglês de crédito devido a um credor no século XVIII, o significado da ameaça de traição da confiança pessoal para o escravo que procurava proteger-se das infindáveis transferências. 


\section{As identidades escravas no século XVIII}

À medida que o século XVII terminava, e principalmente depois de 1700, o brilho do ouro nas planícies de Minas Gerais deu fim à era na qual os símbolos religiosos canalizavam as estratégias de escravos e de senhores em todo o Brasil, como também trouxe homens da África Central, a maioria embarcada através de Luanda de maneira crescente, aos milhares, de Benguela, por volta de 1750. Em Minas Gerais, estes centro-africanos se encontravam com os cativos minas trazidos pela Bahia, de vários contextos da África Ocidental. Eles reconheceram um sentimento de similaridade em termos de suas origens, ao longo do meio século em que foram levados em direção às regiões mineradoras. Pela metade do século XVII, a maioria deles vinha das áreas de línguas kimbundo sujeitas às incursões militares dos portugueses nos dois lados do Baixo Kwanza e das regiões sul dos kikongos, na turbulenta fronteira norte da colônia. ${ }^{40}$

Durante as últimas décadas do século, cativos das terras altas dos umbundos, ao sul do Kwanza, juntaram-se a eles em número crescente, como também a outros tirados das populosas franjas ao sul das florestas equatoriais pelas forças militares emergentes de Ruund (Lunda) estacionadas ao leste do Kasai. Todas as comunidades linguísticas da região, às margens florestais do Kalahari, encontravam-se relativamente difusas e abertas, com indivíduos movendo-se através delas, e também em transição, uma vez que as pessoas formavam novas comunidades para defenderem-se contra a escravização ou para obter vantagens às novas oportunidades de comercializar com o Atlântico. Identidades genéricas como as de "bantu" e de "mina" tenderam a se formar no Brasil, tanto em função de diferentes origens comerciais como de distintos contextos na África Ocidental ou Central.

$\mathrm{Na}$ África Central, as altas terras dos umbundos passavam por uma fase de extrema violência, durante uma geração ou quase, depois da década de 1720, à medida que a fronteira da violência escravagista avançava na região como resposta à demanda de trabalho nas Minas Gerais. ${ }^{41}$ Foi também um tempo de profundos realinhamentos de identidades no interior da difusa comunidade linguística em que os refugiados moviam-se ao encontro de senhores da guerra que pudessem protegê-los das razias, reagrupando-se segundo as políticas de lealdade e de

${ }^{40}$ MILLER. Way of death, especialmente o capítulo 5 para estas e outras fases do avanço da escravidão pelo interior da África Central; o mesmo tema se encontra resumido no texto de MILLER. Central Africa during the era of the slave trade, op. cit.

${ }^{41}$ Para os detalhes desse processo, ver: MILLER, Joseph C. Angola central e sul por volta de 1840. In: Estudos afro-asiáticos. Centro de Estudos Afro-Asiáticos. Rio de Janeiro, nº 32, 1997, p. 7-54. 
identidades locais que iriam maturar como os estados "ovimbundos" no período final do século.

Embora os habitantes das terras altas compartilhassem línguas e outros traços em comum, muitos dos umbundos foram atingidos no processo de criação dessas novas identidades políticas frequentemente conflituosas. Qualquer sentido de uma etnicidade compartilhada em Minas Gerais era tão divisível em alguns contextos quanto unificador em outros. Poderiam ter alcançado número suficiente para produzir bandos autoconscientes e coerentes de recém chegados umbundos, mas somente no Brasil, em contraste aos africanos de outras áreas que eles encontraram aqui, e num nível de generalização que tornava difusas as divisões frequentemente hostis que eles haviam defendido como "wambu" ou "mbailundu" na África.

Uma vez que a variedade crescente das origens dos africanos centrais e a instabilidade da identidade política nos tormentos da escravização em casa, assim como o enorme contraste entre eles e os minas da África Ocidental no Brasil, poderiam promover o mais amplo senso de contextos compartilhados, eles apropriaram-se das distinções comerciais de seus senhores, como angolas ou benguelas, por seus portos de embarque na África. Pequenos grupos de homens vindos do interior podiam usar afinidades étnicas específicas com fins específicos, redes para mútua proteção, mas estas associações eram mais uma tática pragmática do que identidades compreensíveis e até mesmo politizadas.

À medida que os distantes símbolos africanos de unidade ressoaram através dos clamores desestruturantes das conexões escravizantes, estes sobreviventes devem ter ouvido os ecos da África que eles forneceram à cultura do catolicismo popular brasileiro. A proeminência, por volta dos finais do século XVIII, do quase legendário rei do Congo, num tempo em que as pessoas vindas da região do Congo conheciam somente as profundas divisões entre os contendores da sucessão do trono na monarquia do século XVI que reclamavam este título, ou a lendária reputação de Nzinga, líder de estilo imbangala que havia se estabelecido em Matamba no vale do Médio Kwango, na metade do século XVII e que terminou uma longa e eclética carreira como devota convertida à cristandade, em um tempo em que Jinga referia-se a uma rede de fornecedores de cativos adquiridos pelos fornecedores ruund, mais além do leste do rio Kwango, mantiveram-se mais em suas reputações como convertidos à fé cristã - tanto entre os senhores quanto entre os escravos - como as únicas memórias da África. ${ }^{42}$ Se os escravos deram

${ }^{42}$ Esta hipótese interpreta a insistência de John Thornton no catolicismo do Estado do Kongo, visto que Linda Heywood estende agora a ênfase na direção da cristianização inicial das áreas do Ndongo/Matamba, a leste de Luanda, tanto como memória na América, como também realidade 
às memórias africanas uma forma católica nos sacramentos da Igreja, também re-africanizaram o catolicismo dos monarcas convertidos na África.

Os africanos centrais, angolas ou benguelas que atingiram o sul do Brasil na primeira metade do século XVIII também conformaram a geração fundadora da comunidade escrava da cidade do Rio de Janeiro, o crescente porto de desembarque e de repasse de homens a compradores que os comercializavam nas trilhas em direção às áreas de mineração. Poder-se-ia esperar que entre as pessoas juntadas no Rio houvesse uma alta e significativa porção de mulheres e também de servos familiares às convenções do serviço doméstico de Luanda e de outras áreas de influência portuguesa em Angola, cidades comerciais e postos militares ao longo do Baixo Kwanza, propriedades agrícolas ao longo do rio Bengo, e particularmente as áreas residenciais dos mercadores que viviam em torno de Ambaca. ${ }^{43}$ Por volta do século XVIII, estas áreas eram tão lusitanas na cultura quanto africanas, dando sentido à designação ambivalente, corrente entre os estudiosos, como "luso-africanas" ou também "afro-portuguesas". ${ }^{44} \mathrm{O}$ número

na África; isto historiciza as conexões escravizantes para sugerir que os escravos inventaram estes símbolos particulares fora das circunstâncias que eles encontraram em meados do século XVIII no centro e no sul do Brasil, ao invés de criá-los aqui a partir de uma continuidade direta e mecânica da África. Ver THORNTON, John. Kongo and Mbundu religious life in the 16th and 17th centuries, e HEYWOOD, Linda. Portuguese into African: The eighteenth-century central African background to Atlantic Afro-Creole cultures. In: HEYWOOD (ed.). Central Africans and cultural transformations in the American diaspora, p. 71-90 e 91-113, respectivamente. [Nota de tradução: THORNTON, John K. Religião e vida cerimonial no Congo e áreas umbundo, de 1500 a 1700; HEYWOOD, Linda M. De português a africano: a origem centro-africana das culturas atlânticas crioulas no século XVIII. In: HEYWOOD, Linda M. (org.). Diáspora negra no Brasil. Tradução de Ingrid de Castro Vompean Fregonex, Thaís Cristina Cassin, Vera Lúcia Benedito. São Pauo: Editora Contexto, 2008, p. 81-100 e 101-124]. Para o lado brasileiro, consultar KIDDY, Elizabeth. Who is the king of Kongo: A new look at African and Afro-Brazilian kings in Brazil, p.153-82 e Armed rebellions, 1780-1888. Idem, Ibid. [Nota de tradução: Quem é o rei do Congo? Um novo olhar sobre os reis africanos e afro-brasileiros no Brasil, p. 165-191, idem, ibidem]. Antecipamos aqui o novo trabalho de Cathy Skidmore-Hess sobre a histórica Nzinga e o estudo de Linda Heywood sobre a famosa monarca Nzinga na memória de Angola e do Brasil.

${ }^{43}$ Os "ambaquistas" começaram a receber mais atenção dos historiadores; ver SEBESTYÉN, Evá e VANSINA, Jan. Angola's Eastern hinterland in the 1750s: A text edition and translation of Manoel Correia Leitão's “voyage” (1755-1756). History in Africa 26, 1999, p. 299-364; ver também VANSINA, Jan. Ambaca society and the slave trade, c. 1740-1840. Manuscrito não publicado, 1998. Ver também DIAS, Jill R. Estereótipos e realidades sociais: quem eram os "ambaquistas". Texto não publicado apresentado no Seminário CONSTRUINDO A HISTÓRIA ANGOLANA: AS FONTES E SUA INTERPRETAÇÃO. Luanda, 4-8 de agosto de 1997; e DIAS, Jill R. Mudanças nos padrões de poder no hinterland de Luanda: o impacto da colonização sobre os Mbundu. Penélope 14, 1994, p. 43-91.

${ }^{44}$ É bem conhecido seu florescimento na primeira metade do século XIX, particularmente, por meio do trabalho de Jill R. Dias; um resumo pode ser encontrado em DIAS, Jill R. Angola. In: ALEXANDRE, Valentim e DIAS, Jill (coords.). O império africano 1825-1890. In: SERR ÃO, Joel 
provavelmente significativo de luandas entre os cativos no Brasil incluía uma parcela - em grande parte de mulheres e de crianças - que havia experimentado a conexão escravizante do Brasil como continuidade em um contexto cultural, por trás das rupturas e deslocamentos dos membros da comunidade em diferentes propriedades de Ambaca a Luanda e ao Rio de Janeiro.

No momento em que os angolanos, na verdade, poderiam treinar cativos, ou criar crianças em suas casas, para vendê-las como serviçais domésticos valorizados no mercado urbano rico em ouro que se desenvolveu no início do século XVIII no Rio, eles continuaram o modelo ibérico dos séculos XVI e XVII que havia anteriormente contribuído com indivíduos aculturados e proficientes para as cidades da Espanha e para as cidades do Recife e Salvador, no nordeste brasileiro. As mulheres escravizadas mais bem-sucedidas nestas cidades usavam suas habilidades para obter o controle do mercado de abastecimento de alimentos e outras provisões domésticas e serviços nas ruas, estabelecendo uma marcante identidade profissional em suas vestimentas e comportamentos altamente estilizados, como as famosas quitandeiras (kitanda, "mercado" no kimbundo de Luanda, onde a palavra e a profissão eram também essenciais para a vida da cidade). A palavra para tal profissão era africana, mas os produtos não eram característicos das áreas rurais da África Central, e seus serviços foram únicos ao estilo urbano das cidades portuguesas em ambos os lados das conexões escravizantes. Como eles puderam tirar os jovens cativos das regiões da África, as mais remotas à influência portuguesa e cristã que também os acompanhava nas casas do Rio, é uma questão para os historiadores sociais do Rio do século XVIII examinarem. ${ }^{45}$

e MARQUES, A. H de Oliveira (dirs.). Nova história da expansão portuguesa, vol. 10, Lisboa: Editorial Estampa, 1998, p. 319-556. Para o século XVIII, além dos esboços em MILLER. Way of death, ver MILLER, Joseph C. e THORNTON, John K. The chronicle as source, history, and hagiography: The "Catálogo dos governadores de Angola". Paideuma 33, 1987, p. 359-89. Traduzido como A crónica como fonte, história e hagiografia: O Catálogo dos governadores de Angola. Revista Internacional de Estudos Africanos 12-13 [1990], p. 9-55, e MILLER. Feeding the city: Luanda's terreiro público in the eighteenth century. Rascunho do texto apresentado na conferência AFRICA'S URBAN PAST. Londres: School of Oriental and African Studies, 19-21 de junho de 1996). Selma Pantoja elevou o nível dos trabalhos sobre a Luanda do século XVIII em PANTOJA, Selma. Luanda: relações sociais e de gênero. In: II REUNIÃO INTERNACIONAL DE HISTÓRIA DA ÁFRICA - A DIMENSÃO ATLÂNTICA DA ÁFRICA. Rio de Janeiro, 30 de outubro - $1^{\circ}$ de novembro de 1996. Anais. São Paulo: CEA-USP/SDG-Marinha/Capes, 1997, p.75-81, e em PANTOJA, Selma. Traders and farms: Women and the food trade in the city of Luanda from the eighteenth to the nineteenth century. Texto não publicado apresentado em BANTU INTO BLACK: CENTRAL AFRICANS IN THE ATLANTIC DIASPORA. CONFERÊNCIA INTERNACIONAL. Howard University, 16-18 de setembro de 1999. Anais, e outros trabalhos em progresso.

45 Aqui aguardamos ansiosamente pelos resultados da pesquisa de Manolo G. Florentino. Enquanto isso, ver seu texto FLORENTINO, Manolo G. About the slaving business in Rio de Janeiro, 
De forma similar, as estratégias comerciais específicas aos contextos urbanos do Rio através das quais homens escravos forjaram laços de um tipo mais público estão aguardando investigações. Nas cidades brasileiras, os trabalhadores especializados, presumidamente veteranos na escravidão, que trabalhavam como artesãos em troca de rendas (negros de ganho) geralmente formavam corporações ocupacionais a partir de suas especialidades. Por volta dos inícios do século XIX, os recém chegados criavam nações que invocavam particularidades linguísticas e o contexto político da África, provavelmente refletindo a proliferação de ocupações especializadas na complexa e crescente economia urbana das cidades brasileiras. ${ }^{46}$ Esses, então, elaboraram as identidades a partir dos nomes dos portos de embarque, importantes para seus possuidores para subverter a desumanização afirmada pelas denominações impostas para enfatizar seu status como propriedade.

Seria necessário também considerar a utilidade da capoeira como estratégia secreta de disciplina masculina e de defesa mútua, adaptada das escolas de iniciação de adolescentes ubíquos (pelo menos no século XIX) nas áreas a leste do rios Kwango, Kasai e Kunene, de onde se originaram números crescentes de jovens tomados como escravos no Brasil depois da década de $1750 .{ }^{47}$ Esses métodos africanos de associação masculina, por sua vez, responderiam aos massivos deslocamentos de populações à medida que a escravização desenvolvia-se lá e, portanto, como produto da própria conexão escravizante, uma experiência crescentemente indistinguível de suas origens na África na medida em que as pessoas moviam-se e reformulavam-se através do continente em resposta ao comércio atlântico. Similaridades, mais do que conexões por meio de transmissões da África e sua preservação no Brasil, podem ter sido simultâneas, elaborações paralelas de novas formas de unir refugiados da escravidão em comunidades

1790-1830: a contribution. In: CRUZET, François, BONNINCHON, Phillippe e ROLLAND, Denis (ed.). Pour l'histoire du Brésil: Hommage à Katia de Queirós Mattoso. Paris: L'Harmattan, 2000, p. 394-416; e Biographical database for Rio de Janeiro. Texto não publicado do Workshop Database Construction and African Diaspora. Toronto: York University, 2-12 de julho de 2002, e FLORENTINO, Manolo G. e GÓES Roberto de. L'enfance asservie: les esclaves du Brésil aux XVIIIe et XIXe siècles. In: HENRIQUES, Isabel Castro e SALA-MOULINS, Louis (ed.). Déraison, esclavage ideologiques et juridiques de la traite négrière et de l'esclavage. Paris: Éditions Unesco, 2002, p. 349-63.

${ }^{46}$ Como elaborado por KARASH, Mary C. Slave life in Rio de Janeiro 1808-1850. Princeton: Princeton University Press, 1987, e inúmeros estudos menores. [Nota de tradução: A vida dos escravos no Rio de Janeiro (1808-1850). Tradução de Pedro Maia Soares. Sao Paulo: Companhia das Letras, 2000).

${ }^{47}$ Para o trabalho atual, ver DESCH-OBI, T. J. Combat and the crossing of Kalunga. In: HEYWOOD (ed.). Central Africans and cultural transformation in the American diaspora; e Angolan martial art traditions in Brazil. Texto não publicado apresentado na CONFERÊNCIA BANTU INTO BLACK. 
vizinhas mantidas pelos mais velhos na África, mas de gangs de adolescentes sob a escravidão no Brasil. ${ }^{48}$

O ambiente crescentemente mercantilizado das cidades brasileiras no século XVIII, como também o crescente significado das garantias de propriedade por um governo secular, intensificou a ameaça de transferências contínuas por meio da venda. Os escravos então ameaçados apropriavam-se das estratégias comerciais e das leis de proteção da propriedade para defenderem quaisquer laços familiares ou de patronagem que eram capazes de elaborar na busca de oportunidades de manumissão.

No contexto brasileiro de instituições de governo civil relativamente fracas, os escravos deixados aos senhores particulares adaptavam suas questões de patronagem responsável dos sacramentos religiosos do século XVII às oportunidades civis e comerciais do século XVIII. Senhores e senhoras continuavam a alforriar em nome das antigas piedades da patronagem pessoal, particularmente para filhos dos senhores nascidos nas casas patriarcais de mães escravas, mas outros escravos eram capazes de ganhar dinheiro nas ruas das cidades, estabelecendo contratos com seus senhores que os obrigavam a pagar uma porção de seus ganhos, talvez por muitos anos, por sua alforria em qualquer momento do futuro em que tais pagamentos atingissem um valor comercial. O preço estabelecido não representava uma avaliação de mercado, pois o arranjo não previa um rompimento das relações senhor - escravo por meio da venda, uma vez que este acrescentava uma garantia financeira que convertia a conexão pessoal em uma forma de patronagem mais duradoura, por meio - de fato - da compra da parte do senhor que poderia incentivá-lo a converter em dinheiro o valor do escravo dispondo-o a outros.

Esses contratos de autoaluguel, desta forma, não terminavam a conexão, mas deixavam os escravos como clientes, em posição de crescente autonomia, não mais sujeitos a transferências arbitrárias, mas capazes de se ligar a outros patrões por meio de empregos, ou de formas voluntárias de associação com outros escravos na comunidade urbana, de acordo com suas vontades e escolhas. A manumissão trazia não a liberdade no sentido norte-americano de direitos civis reconhecidos, mas a liberdade de construírem identidades preservando as redes pessoais de sua posse.

Quando o boom do ouro declinou por volta da década de $1760,{ }^{49}$ as plantações de açúcar da capitania do Rio de Janeiro constituíram a região do Brasil na qual os

\footnotetext{
${ }^{48}$ Ver também VOGEL, Arno, MELLO, Marco Antonio da Silva e BARROS, José Flávio Pessoa de. $A$ galinha-d'Angola: iniciação e identidade na cultura a fro-brasileira. Rio de Janeiro: Falcso, 1993.

49 Os sobreviventes da escravidão em Minas Gerais começaram a se reproduzir neste momento e, relativamente, poucos novos cativos atingiram a região. O processo de formação da comunidade
} 
africanos juntaram-se em número suficiente para formar identidades comunitárias independentes das propriedades senhoriais. Em números que excediam quaisquer outros previstos para a população escrava no Brasil, eles vinham através de Luanda, e possivelmente de Benguela, sendo da mesma diversidade crescente de lugares na África Central que os anteriores, os quais permaneceriam na cidade do Rio.

Eu não estou familiarizado com pesquisas que identifiquem os tipos distintos de comunidades que foram criadas neste momento formativo do último boom da produção açucareira brasileira, e pode ser que as massas de estranhos jogados juntos tenham trabalhado implacavelmente durante o início de uma nova indústria rural, em plantações isoladas, sem predecessores capazes de intermediar suas relações com a arbitrariedade frustrante de seus senhores e que, faltando sucessores, criaram menos estratégias próprias do que seus correlatos nas cidades do Brasil. $^{50}$

A escravidão no Brasil impôs expectativas de gênero diferentes sobre meninas e meninos daquelas das crianças que cresceram na África, onde a ênfase no controle masculino da fertilidade e da reprodução feminina criaram papéis fortemente diferenciados, mas comparavelmente valorizados de acordo com as funções sexuais. Na África, a escravidão tendeu a recair sobre as mulheres, que eram retidas pelos homens por sua capacidade de procriar sem competir com as lealdades das parentelas femininas, pelo menos em parte significativa. As conexões escravistas trouxeram homens e mulheres para o Brasil em proporções desequilibradas, talvez duas vezes mais homens do que mulheres ao longo de

entre os escravos teria, portanto, extraído mais e mais das experiências das jovens gerações de nativos afro-brasileiros, bem como da sociedade em transformação que eles encontraram enquanto adultos, e das crescentes adaptações indiretas da memórias da África de seus pais. Suas experiências são paralelas às dos escravizados nos Estados Unidos.

${ }^{50}$ Deve-se também levar em conta, neste período, a retomada do fornecimento de número significativo de novos cativos para Pernambuco e para as capitanias do norte, a maioria destinada aos serviços das novas plantations de algodão criadas para tirar vantagem da crescente demanda britânica por fibras têxteis. Eles têm recebido relativamente pouca atenção acadêmica; os trabalhos publicados até agora concentram-se em grande medida nas últimas fases da escravidão nessa região, durante o século XIX. Suspeita-se que os escravos do Alta Guiné e os minas da Costa dos Escravos, que entraram pela Bahia, teriam dominado a fase inicial. Para as décadas de 1750 e 1760, com a Companhia Privilegiada do Maranhão, inauguram-se estes fornecimentos; ver CARREIRA, António. As companhias pombalinas do Grão-Pará e Maranhão e Pernambuco e Paraíba. Lisboa: Presença, 1983, nova edição revisada; e DIAS, Manuel Nunes. Fornecimento ultramarino e mercantilismo: A Companhia Geral de Grão-Pará e Maranhão (1775-1778). Revista de História 36, $\mathrm{n}^{\mathrm{0}} 73,1968$, p. 71-113. Indicações sobre as estratégias que esses escravos adotaram podem ser encontradas em FIGUEIREDO, Aldrin Moura de. Reis de mina: a Irmandade de Nossa Senhora do Rosário dos Homens Pretos no Pará do século XVIII ao XIX. Boletim-Museu Paraense Emílio Goeldi (série Antropologia) 9, nº 1, 1993, p. 103-21. 
grande parte do tráfico. Além da identidade comercializada, isso reduziu a população em suas funções produtivas em benefício de outros, e privou os africanos de sua progenitura, reproduzindo-os através da violência e da compra.

Para as mulheres a família importava mais, na América como na África, e isso ocorreu crescentemente no século XIX na medida em que as levas de cativos que atingiam o Brasil incluíam cada vez mais jovens, e mesmo crianças, sem uma experiência significativa para além do lar de seus pais, ou de estrangeiros na África que os mantiveram por um tempo breve como dependentes no interior de suas moradias. ${ }^{51} \mathrm{~A}$ vantagem do rapto e da escravização de crianças, violentamente afirmada na África, era de que elas cresciam sem memória de seus contextos primários, identificando-se completamente com as conexões formadas pela escravização. Poderiam relembrar ou reconstruir mais nas Américas sob a pressão da escravidão? A minoria feminina tendeu a se concentrar nas posições domésticas, em que elas estavam em condições de se identificar com os senhores, somente superando a esterilidade da escravização, procriando crianças que lhes dariam as identidades e as esperanças no futuro.

Uma vez que as gerações nascidas no Brasil incluíram tanto homens quanto mulheres, as mulheres entre esta população escrava eram americanas, familiarizadas com a África somente através das memórias de suas mães. As primeiras populações masculinas nascidas na África e trazidas à América encontravam-se isoladas nos campos e nas minas. As mulheres tendiam a se identificar como brasileiras, antecipando e orientando suas crianças nascidas nas Américas em direção às conexões de tipo mais privada e doméstica, através dos ritos da Igreja Católica e das habilidades em manipular os ambientes urbanos e domésticos.

A população rural masculina, constantemente reforçada pelos novos aportes da África, apropriou-se da etnicidade comercial atribuída aos escravos vindos da África, desenvolvendo associações de ofícios, afiliações voluntárias para ajuda

${ }^{51}$ O ponto de partida da maioria das narrativas dos escravos oriundos da África Ocidental, particularmente dos indivíduos jovens que sobreviveram para recordar suas perdas; ver, a propósito, CURTIN, Philip D. (ed.). Africa remembered: Narratives by West Africans from the era of the slave trade. Madison: University of Wisconsin Press, 1967; reeditada por Prospect Heights, Ill: Waveland Press, 1997, incluindo o famoso texto de Olaudah Equiano; também CARRETTA, Vicenti (ed.). Olaudah Equiano: The interesting narrative and other writings. Nova York: Penguin Books, 1995. Um testemunho revelador da intensidade dessas memórias para uma mulher escravizada em Barbados é encontrada em HANDLER, Jerome S. Life histories of enslaved Africans in Barbados. Slavery and Abolition 19, 1988, p. 129-41. Para o Brasil, ver também a estrutura da história de Domingos elaborada por MILLER. Way of death, p. 1-5. Para um resumo recente das estatísticas, ELTIS, David e ENGERMAN, Stanley L. Fluctuations in sex and age ratios in the transatlantic slave trade, 1664-1864. Economic History Review 46, n² 2, 1993, p. 308-23; e KLEIN. Atlantic slave trade. 
mútua e outras formas, particularmente para confirmar as identidades por meio de funerais em que se reuniam, e sociedades do tipo gangs, iniciáticas, para proteção contra outros africanos. Homens e mulheres criaram identidades americanas de gênero paralelas às que haviam conhecido na África - as mulheres orientadas para a educação de seus filhos e os homens, de acordo com suas habilidades profissionais, a manutenção de comunidades e a juventude beligerante - mas alteravam-nas para buscar recursos disponíveis na escravidão e para sobreviver aos constrangimentos impostos pela escravização.

As identidades sociais, contextuais, efêmeras e mesmo oportunistas criadas pela necessidade decorrente da fragilidade e transitoriedade das afiliações pessoais no contexto da permanência na escravidão encorajaram os escravos a trazer consigo sua consciência africana de identidades múltiplas e instrumentais então evidentes na América. Seria possível, portanto, para um mesmo menino escravizado no Brasil, identificar-se, por seu contexto familiar, ao homem do interior capaz de reconhecer os parentescos que ele perdeu, a aldeia ou região em que ele residiu quando se encontrou na companhia de outros de uma mesma área na qual as pessoas conheciam as respectivas famílias, como ganguela (ngangela, o termo coletivo que os povos falantes de kimbundo ou umbundo, mais ao oeste, atribuíam às fluidas comunidades que vivam dispersas pulverizadas nas planícies secas e arenosas ao leste do Alto Kwuanza e Kunene), onde os escravagistas de Angola agrupavam-nos em um comboio de escravos, juntamente com outros vindo do Ruund, ou de Nyaneka, ou das terras dos umbundos. Depois ele poderia ser reconhecido como benguela, angola ou luanda-dependendo do porto através do qual ele, e uma grande variedade de outros trazidos com ele, seriam transportados, de forma torturante, para o Brasil - quando se confrontaria com senhores, potenciais compradores ou autoridades legais no Rio de Janeiro ou Minas Gerais.

Tais pessoas estavam preocupadas somente com o seu status de propriedade e mais interessadas em sua personalidade comercial do que em sua ancestralidade, capacidades linguísticas, ou quaisquer outras dos muitos lados que conformavam sua humanidade completa, do indivíduo multifacetado em que a vida o havia tornado. Homens das distantes áreas rurais a leste do alto rio Kunene, longe das ações dos missionários ativos na Angola portuguesa, batizados em Benguela da forma mais corrente, poderiam igualmente sentir o poder do rei cristão do Congo como um brado de revigoramento sobre a escravidão católica, mesmo que eles nunca tivessem ouvido os competidores por este título na África.

Os escravos eram, então, adeptos de apresentar-se em situações em que eles se encontravam, particularmente em reação à incapacitação da escravidão. Os historiadores deveriam, portanto, considerar as expectativas dos autores de qualquer 
fonte nas quais eles encontrem escravos nomeados (designados), ou nomeando-se a si mesmos, por qualquer origem singular em África: as reivindicações mais sinceras e calculadas de um escravo sob estas circunstâncias devem ter sido guiadas por uma estratégia que refletiu o aforismo do século XIX acerca do qual os portugueses no Brasil também se definiram, orgulhosa e desafiadoramente, em reação aos poderosos ingleses que havia entre eles: para o inglês ver, astutamente suprimindo a responsabilidade que implicaria dizer: "como desejamos que os ingleses o vejam". Os escravos se apresentaram também a seus senhores com um grau maior de dependência deles do que de fato tinham.

\section{Status civil e raça - 0 século XIX}

A última fronteira da escravidão no Brasil desenvolveu-se no século XIX, com o aumento da produção do café nas colinas de São Paulo, no interior do Rio e no sul de Minas Gerais. O café, por sua vez, deu suporte à consolidação da identidade civil dos "brasileiros", distinguidos depois da declaração de independência política em 1822 da identidade portuguesa associada com as regras coloniais e com as muitas e diversas capitanias herdadas, e focou-se no império proclamado independente. Os britânicos, muito envolvidos com Portugal, e também os maiores investidores por trás do crescimento de novos setores da economia no Brasil do século XIX, eram apontados ofensivamente como credores e abolicionistas contraditoriamente inclinados a romper as conexões escravizantes das quais os brasileiros dependiam para lavrar os estados cafeeiros em uma vastidão tropical. Os africanos, e a escravidão, tornaram-se uma presença sensível no centro da formação da identidade brasileira.

A demanda por mão de obra ajudou a direcionar a importação de africanos para o Brasil, entre os anos 1790 até o fim do mercado transatlântico em 1850, a números nunca antes alcançados e expandiu as conexões escravizantes a uma vasta disposição de novas regiões na África, além de continuar a explorar as fontes já estabelecidas de cativos de Luanda a Benguela. Ao leste de Benguela, as pessoas das terras altas centrais adquiriram suas modernas identidades como "ovimbundu" em contraste a pessoas não inteiramente diferentes, a quem as caravanas encontraram nas margens do deserto de Kalahari, ao longo do Alto Zambezi, e nas florestas além de Kasai, virtualmente no centro do continente.

Eles mantiveram muitos - talvez a maioria dos cativos que adquiriram ali-e assim suas novas identidades coletivas como "ovimbundu", representando os padrões locais de comportamento pelos quais eles julgaram deficientes os estranhos entre eles; a etnicidade representava as medidas culturais de respeitabilidade que 
distinguiam aqueles nascidos (para eles) de imigrantes simultaneamente identificados e marginalizados como alienígenas. A moderna etnicidade na África, então, teve sua urgência suscitada pela reação nativista aos estrangeiros que a escravidão introduziu em todos os lugares, tornando as identidades coletivas análogas a "branquitude" alcançada nas Américas através de barreiras erguidas em termos raciais.

Mercadores em Luanda parecem ter controlado as áreas dos falantes de kikongo do norte da zona de ocupação militar portuguesa em uma extensão maior do que eles mantinham no século XVIII. ${ }^{52}$ Após a retirada dos britânicos do mercado atlântico em 1808, os escravagistas brasileiros afluíram para a costa norte de Luanda-Ambriz, os bancos do baixo rio Zaire, Cabinda, Malimba e outros portos ao longo da costa Loango - anteriormente dominados pelos britânicos e franceses. Ali eles também adquiriram mais falantes de kikongo e mais cativos de regiões remotas no centro do continente trazidos de fontes de falantes kikongo, mais do que nunca antes na história do mercado; pela primeira vez a área perturbada pela escravização se estendeu para o interior do Zaire e suas principais tributárias. ${ }^{53}$

Outros escravagistas do Rio começaram a circular o cabo da Boa Esperança para comprar cativos de Quelimane, Inhambane, Delagoa Bay e em postos de comércio reclamados pelos portugueses ao longo da costa sudoeste da África; pelos anos 1820 e 1830, os "moçambiques" que trouxeram com eles tornaram-se uma presença visível no sul do Brasil devido tanto ao seu número, quanto à novidade. Os plantadores de café, cada vez mais ao longo do século, construíram as forças de trabalho em suas plantations também por meio da compra de escravos - alguns originários do leste da África, e mais e mais deles eram nascidos brasileiros, oriundos das economias menos dinâmicas do nordeste brasileiro. As distinções relevantes nesse processo de mistura tendiam em direção da identificação genérica e inclusiva dos africanos do centro e do sudoeste como "bantu".

Do nordeste do Brasil, os pernambucanos retornaram, apesar de que numa escala relativamente menor, para Luanda e para as costas do norte, assim como o fizeram os baianos reunidos no porto de Cabinda, que os franceses haviam abandonado no início dos anos 1790 durante as guerras que se seguiram à Revolução Francesa. Os baianos, no entanto, se concentraram em suas fontes já estabelecidas de cativos em Uidá e outros portos ao longo da Costa Ocidental de Escravos

${ }^{52}$ FERREIRA, Roquinaldo Amaral. Slavery and the illegal slave trade in Angola, 1830-60. Texto não publicado apresentado no ENCONTRO ANUAL DA AMERICAN HISTORICAL ASSOCIATION, Seattle, 1998, e outros textos mostram as grandes proporções de "congo" em Luanda na década de 1840 .

${ }^{53}$ HARMS, Robert W. River of wealth, river of sorrow: The Central Zaire Basin in the era of the slave and ivory trade, 1500-1891. New Haven: Yale University Press, 1981. 
Africanos (mina). Assim como na África central, nessa época as áreas desses portos de escoamento de cativos se estenderam muito para dentro do continente, encontrando grupos de mulçumanos das margens do deserto do Saara.

Nos conflitos intensos resultantes, característicos das fases iniciais da escravização em todos os locais da África, os clérigos mulçumanos dali reagrupavam as vítimas e refugiados para defenderem-se por trás das bandeiras do islã e, assim, a violência ficou conhecida como as Jihads, "guerras justas" travadas em nome do islã. Essas guerras enviaram a primeira grande onda de mulçumanos, em quantidades desproporcionais de homens, aos portos de escravos da Costa dos Escravos, onde os baianos os compraram.

A região próxima à costa de Uidá naquela época também caiu em um longo período de estado de guerra agonística, produzindo uma onda de cativos falantes de yorubá, conhecidos no Brasil como nagôs. Retirados do delta do Niger pelos britânicos, onde eles haviam concentrado sua escravização no final do século XVIII, abriram os centros de troca ali também para os baianos, permitindo-lhes introduzir pessoas das áreas igbo do baixo Niger - tipicamente incluindo mais mulheres do que outras correntes no mercado atlântico - pela primeira vez. Os meninos e adolescentes do sexo masculino da África central, homens mulçumanos do oeste da África sudanesa, falantes de yorubá, e mulheres e homens igbo - todos chegaram como grupos alienados em comunidades escravas no nordeste brasileiro que haviam começado a se misturar, através de décadas de chegadas relativamente estáveis por Uidá, uma população genérica de minas, com um crescente componente de afro-brasilidade de crianças nascidas e criadas no Brasil.

As pessoas que chegavam da África neste estágio tardio da conexão escravagista brasileira vieram, então, de uma ampla gama de regiões e relativamente poucos deles se concentravam em números suficientes para se organizarem de maneira pública e visível, com base em origens compartilhadas. Os recém chegados certamente criaram redes informais de conterrâneos para ajudarem-se mutuamente a superar o isolamento de sua escravização, particularmente nas cidades, mas estas nações foram instituições americanas que, enquanto certamente serviram bem aos recém chegados por funcionarem como um tipo de adaptação de suas línguas africanas maternas, antes que aprendessem português, não acarretaram significativamente precedentes específicos - incluindo os dialetos locais - na terra natal de qualquer um de seus membros.

A urgência pragmática de sobreviver à escravidão certamente superou as ligações afetivas ao mundo que haviam perdido, exceto nos sentidos mais pessoais. Eles também enfrentaram um mundo, no início do século XIX na América, no qual as instituições civis - em particular a polícia - estavam suplementando a autorida- 
de pessoal dos senhores no papel de vigilância e disciplina. A partir daí, estratégias em tons seculares e públicos substituíram os idiomas sacramentais nos quais seus predecessores haviam se organizado através das irmandades ligadas à igreja, casamentos, batismos e apadrinhamentos, ou os registros comerciais nos quais as últimas gerações de propriedade humana haviam negociado com os proprietários.

Adicionalmente, as populações de escravos estabelecidas, a quem os africanos que chegavam se juntavam no Rio e nas províncias mais antigas do nordeste, incluíram menos e menos nascidos africanos, uma vez que a reprodução começou a gerar grupos de jovens afro-brasileiros. Nascidos em meio cultural americano e frequentemente conectados a um patrono (padrinho) entre os senhores, eles estavam em posição de reclamar qualquer liderança pública que estivesse disponível e a fazê-lo em termos cada vez mais brasileiros.

Os africanos continuaram a organizar-se ao longo das antigas linhas de identidades desenhadas a partir de suas origens no outro lado do Atlântico somente onde os modelos em alteração do comércio atlântico rearranjaram-nos em novos grupos, numerosos e distintamente diferentes. Os "moçambiques" no sudeste do Brasil parecem ter visto a si próprios como diferentes neste tipo de sentido prático e implementável nas Américas, mais do que em experiências específicas em qualquer lugar dentro das largas porções da África sudoeste de onde se originaram, ou inúmeros portos de embarcação espalhados ao longo de um milhar de milhas de costa, da ilha de Moçambique à baía de Lourenço Marques. ${ }^{54}$

$\mathrm{Na}$ Bahia, o fluxo de capturados (cativos) vindos dos conflitos nas regiões de língua yorubá e das áreas mulçumanas até o norte da Costa dos Escravos forneceu o exemplo mais notório do efeito catalítico - no Brasil - de um grande número de recém chegados perceptivelmente diferentes após 1810 e nos anos $1830{ }^{55}$ Incapazes de encontrar lugares para si próprios, suspeita-se, nas comunidades de escravos já então estabelecidas, de pequenos grupos desses homens que, talvez utilizando de lealdades paroquiais formadas nas guerras que os levaram ao

${ }^{54}$ E eles parecem ter tido mais sucesso na retirada para as comunidades maroon, quilombos, entre as fronteiras relativamente abertas das províncias do norte. Para o caso do oeste brasileiro, ver KARASCH, Mary C. Os quilombos do ouro na capitania de Goiás, p. 260-62, e VOLPATO, Luiza Rios Ricci. Quilombos em Mato Grosso: resistência negra em área de fronteira, p. 240-62, ambos em GOMES, Reis e. (eds.). Liberdade por um fio; e KARASCH, Mary C. Guiné, Mina, Angola, and Benguela: The impact of African cultural traditions in the captaincy of Goiás, 1780-1835. In: HEYWOOD (ed.). Central Africans and cultural transformations in the American diaspora, p.117-51. [Nota de tradução: Centro-africanos no Brasil Central, de 1780 a 1835, p. 127-164. In: HEYWOOD, Linda M. (org.). Diáspora negra no Brasil, op. cit.]

55 LOVEJOY. Background to rebellion. LAW, Robin e LOVEJOY, Paul E. Borgu in the Atlantic slave trade. African Economic History 27, 1999, p. 69-92. 
escravizamento, tenderam a retroceder em redutos maroons, ou a levar consigo as línguas comuns - ou pelo menos relatadas - que falavam para subordinar a hostilidade em suas origens à sua necessidade de colaborar no Brasil. ${ }^{56}$

Os adultos muçulmanos masculinos teriam encontrado em sua fé partilhada um veículo, além da salvação no outro mundo, tanto para alívio (conforto) quanto para autoajuda nas tribulações mundanas da escravidão brasileira. Seus perfis parecem ter levado seus compradores a empregá-los em buscas urbanas em que - na mais famosa e excepcional instância de escravos sustentando-se através de conexões que haviam trazido de suas origens africanas - um grupo de recém chegados, somados aos contatos que desenvolveram em outros segmentos da população de escravos da Bahia e encorajados (estimulados) pela familiaridade com suas circunstâncias americanas, tentaram a famosa rebelião dos malês de $1835 .^{57}$

Essa revolta aconteceu em um estágio crítico e transitório entre o abandono da África e a vinda a termos para a América, um momento no qual corriam informações suficientes para se arriscar uma rebelião, mas de reconhecimento insuficiente para prever seus riscos; o conhecimento, apesar de reduzido, acabou tornando-se uma tentação perigosa e a revolta falhou, traída em parte por escravos de outras crenças. As mulheres falantes de igbo e os jovens da África central tenderam a misturar-se em comunidades crescentemente afro-brasileiras que seus predecessores haviam estabelecido e, portanto, constituíram presenças menos visíveis por características atribuídas à África.

Mais comumente, as pessoas escravizadas no Brasil no século XIX, particularmente no nordeste, alteraram suas estratégias de afirmação de suas identidades coletivas para resistir ao abrasileiramento que estava ocorrendo em todos os locais. Um fluxo crescente de imigrantes vindos da Europa, incluindo muitos não portugueses, forçou a mistura heterogênea de sujeitos livres dos imperadores no Brasil para definirem suas identidades públicas em termos "nacionais", transformando a raça no elemento que os unificava.

As pessoas de descendência africana, incluindo cada vez maiores proporções de crianças nascidas no Brasil, buscaram cada vez mais lugares como

\footnotetext{
${ }^{56}$ Para esse aspecto crucial dos quilombos, ver GOMES, Flávio dos Santos. Ainda sobre os quilombos: repensando a construção de símbolos de identidade étnica no Brasil. In: REIS, Elisa, ALMEIDA, Maria Hermínia Tavares de e FRY, Peter (orgs.). Política e cultura: visões do passado e perspectivas contemporâneas. São Paulo: Anpocs/Hucitec, 1996, p. 197-221; e GOMES, Flávio dos Santos. História, quilombo, invenção de cativeiro e liberdade. Cadernos do CFCH (Revista do Centro de Filosofia e Ciências Humanas da Universidade Federal do Pará). Belém 12, nº 1-2, 1996, p. 99-140.

57 O definitivo e certamente clássico estudo é REIS. Slave rebellion in Brazil, op. cit., no qual elabora as circunstâncias e conexões locais que transcendem qualquer simples interpretação "étnica" da trama.
} 
afro-descendentes. Eles distinguiam-se em sociedades religiosas amplas, autônomas e fundamentalmente brasileiras que caracterizaram os idiomas africanos proeminentes, traçando metáforas específicas a partir das conexões do yorubá trazidas pela última onda de escravos importados; novos deuses louváveis pela sua inovação. Esses sucessores independentes das irmandades paroquiais do século XVIII tornaram-se as famosas comunidades religiosas nordestinas do Brasil de candomblé e umbanda e outras reinvenções de metáforas culturais genericamente africanas como símbolos de resistência à escravidão, inventando identidades como africanos em reação à exclusão racial na América. ${ }^{58}$

Essas estratégias modernas de construção comunitária permaneceram inclusivas e abertas, precisamente o oposto da particularidade e exclusividade implicada pela especificidade étnica das metáforas africanas de que eles se apropriaram: qualquer um poderia participar e os deuses yorubás, em sua vestimenta brasileira, melhor representaram os "africanos" no sentido genérico emergente de afrobrasileiro, do que qualquer "comunidade falante de yorubá" que os escravos que as introduziram tenham trazido como recordação da África.

Assim como as primeiras estratégias de cura, as inovações em relação aos deuses dos nagôs tiveram um apelo para os afro-brasileiros e para os africanos que não falavam yorubá, não porque eles fossem velhos e familiares, mas precisamente porque eram novos, não testados e, portanto, cheios de esperanças. Eles também entenderam os precedentes de identidades autônomas e individualizadas, criadas por escravos assimilados da cidade, homens e mulheres que "compraram" a si mesmos, e formaram associações ocupacionais em ruas urbanas para os trabalhadores rurais das plantações e, particularmente, as mulheres enquanto enfrentavam a assimilação como brasileiras subordinadas.

Esses pontos de reagrupamento cultural, consequentemente, também atraíram mais e mais porções de populações brasileiras reconhecidas e excluídas como descendentes de africanos quando a escravidão caminhava para seu final no Brasil, em 1888. Como africanos, eles converteram os símbolos de sua exclusão das maiores comunidades de brasileiros em estratégias intensamente coletivas para sobreviver à sua marginalização como americanos. Eles eram suspeitos na sociedade mais ampla porque mantinham seus rituais secretos, mas eram tolerados

${ }^{58}$ BUTLER, Kim D. Africa in the reinvention of nineteenth-century Afro-Bahian identity. Texto não publicado, apresentado na conferência RETHINKING THE AFRICAN DIASPORA. Para a complexa interação de identidades africanas e brasileiras neste último estágio na longa e tortuosa história da conexões escravizantes no Brasil, ver MATORY, J. Lorand. The English professors of Brazil: On the diasporic roots of the Yorùbá Nation. Comparative Studies in Society and History $41, n^{\circ} 1,1999$, p. $72-103$. 
porque seu idioma religioso os fez parecer irrelevantemente inofensivos em uma época em que a discordância política era o desafio mais perigoso à sociedade civil emergente. As metáforas religiosas africanas se moveram de profundamente ameaçadoras, nos primeiros tempos de crença, para apresentarem-se benignamente exóticas em uma época de avanço tecnológico secular.

Conforme a escravidão "secava" quanto à importação de novas pessoas da África, tendo tudo acabado em 1850, distinções refinadas de tons de pele entre a população colored substituíram o antigo contraste entre os experimentados ladinos católicos, falantes de português (indivíduos aculturados) e os destreinados (indisciplinados), ininteligíveis "brutos” da África (indivíduos não aculturados). As comunidades e conexões que os escravizados haviam formado eram submissas às afiliações permanentes, que os afro-brasileiros definiram como "negras", e contra a exclusão da ordem racista de progresso definida no Brasil do fim do século como europeia, em contraste à definição da África tradicional, e que aqueles excluídos então abraçaram com propósitos próprios. Para os afro-brasileiros nascidos na América, a África tornou-se uma memória construída mais do que uma experiência a partir da qual construíram suas identidades. Essas estratégias, por sua vez, sobreviveram ao fim da escravidão como centros vitais da identidade espiritual e comunitária de muitos brasileiros de hoje.

\section{Conclusões: a conexão da escravização no Brasil como história e memória}

Herdeiros progressivos do Iluminismo europeu consideram a história como mudança e suas alterações como cumulativas e irreversíveis; nessa perspectiva, nós nunca podemos voltar para "casa" novamente. Se o "eu" (self) for visto como uma identidade inata e estável que lutamos para realizar como crescimento e desenvolvimento a partir de uma infância amorfa deixada para trás, é claro que falhamos. Em um ambiente capitalista, nós também acumulamos materialidade para nos tornarmos - em graus significativos - o que possuímos.

Os africanos, em contraste, construíram identidades fluídas a partir de uma sucessão de circunstâncias nas quais se encontraram, como reconhecíveis pelas pessoas com quem eles puderam estabelecer relações de respeito, seguras e inquestionáveis; eles "se tornaram" a companhia que mantiveram. Eles fizeramse como centros de "teias/redes" pessoais que puderam construir. A violência do comércio escravagista reduziu-os a não identidades anônimas e sem poder, fazendo com que cada conexão que eles criaram fosse arbitrariamente cortada por outros. 
Compreender as conexões escravizantes como os escravos devem tê-las experimentado requer que estendamos nossa suspensão das premissas modernistas às maneiras pelas quais eles reagiram à sua súbita perda do que lhes era familiar e confortável: através da retenção do que puderam, recriando em novas formas as partes que não puderam reter, e relembrando, de maneiras complexas, tudo para restaurar as conexões sociais que os faziam ser quem eram.

Aqueles nascidos na África, mas desenraizados e trazidos para a América, devem ter aplicado associações compartilhadas de suas vidas nas praias opostas do Atlântico diretamente para circunstâncias inteiramente novas em que viveram. Somos nós que tentamos compreender o que fizeram, traçando continuidades na forma e nas metáforas, na perspectiva da ênfase modernista da história como mudança, como recriação, no presente, de um passado, conforme este foi experienciado. No entanto, agora está se tornando claro que os africanos experimentaram as mudanças que sempre ocorreram na África em premissas conceituais que reverteram essa estratégia: eles encontraram mudança, não por uma ênfase na crescente distância de tempos idos como perdas somando o revestimento rosado do passado relembrado que nós geramos, mas especialmente como uma oportunidade para preservar a continuidade, começando de um passado idealizado para o qual eles devem converter o presente $^{59}$ que eles então abordaram como um desafio restaurativo mais do que uma lamentação do passado como uma perda irrecuperável. O passado que experimentaram como conexão mais do que separação, e a raiva de seus ancestrais sempre os lembrava disso quando eles os abandonavam.

Na prática, eles perceberam o passado no presente, pela interpretação das circunstâncias nas quais eles se encontraram como aspectos quase sempre sutilmente camuflados e difíceis de reconhecer de onde e quando eles significaram ser. O que não podiam ajustar, eles tendiam a aceitar como destino, não importando o quanto fosse inexplicável. $\mathrm{O}$ aspecto mais africano das lutas dos africanos por identidade sob a escravidão era, portanto, a adaptabilidade com a qual eles re-sintonizaram ecos específicos de seus passados pessoais para repercutir coletivamente nas circunstâncias inovadoras que encontravam nas Américas.

\footnotetext{
${ }^{59}$ A afirmação mais clara que eu conheço sobre este insight está no trabalho de COOPER, Bárbara M. Marriage in Maradi: Gender and culture in a Hausa society in Niger, 1900-1989. Portsmouth, N.H.: Heinemann, 1997, capítulo de conclusão. Note que Cooper passou a apreciar essa distinção em um ambiente muçulmano. Tenho a impressão de que a ênfase com a qual estou caracterizando o "africano" prevalece em ambas as visões históricas, muçulmana e não muçulmana, bem como em outras visões da "história" em qualquer parte do mundo, pois é o Ocidente moderno que é único.
} 
Os africanos e, posteriormente, os afro-brasileiros se conectaram a uma África de muitos significados diferentes como raízes a partir das quais eles iriam conectar suas vidas sob a escravidão na América, tentando restaurar a continuidade ordenada que qualquer um buscaria manter em face dos rompimentos pessoais arbitrários, das crises de identidade, das transferências para uma inovação isolante, terrivelmente inexorável, de proporções recorrentes. A escravidão comercial foi quintessencialmente histórica no moderno sentido de uma descontinuidade imprevisível e incompreensível. No entanto, eles poderiam não depender da preservação de metáforas específicas que impressionam os modernistas ocidentais como "conectando" os escravos do Brasil de volta à África para criar um sentido de continuidade através de sua escravização.

Preferencialmente, como eles sutilmente converteram a comunhão católica e a propriedade capitalista em estratégias de pertencimento no sentido africano, ou técnicas africanas adaptadas de consolidação de laços de patronagem e clientela, para contar a efemeridade de seus laços como escravos no Brasil, eles lutaram das maneiras que haviam aprendido em casa para restaurar um senso de continuidade sem costura para a estrutura alugada de suas vidas, não por identidades em termos de onde eles vieram, uma vez que eles tinham irreversivelmente perdido suas origens ancestrais, exceto na morte, mas especialmente através das novas conexões que eles construíram para sobreviver, para serem reconhecidos, para tornarem-se visíveis uns aos outros em meio ao anonimato despedaçado da escravidão na qual eles viveram: de suas conexões confirmadas, portanto estabelecendo identidades, pela busca de oportunidades oferecidas pela cultura de seus senhores em formas que mudaram também da devoção eclesiástica e sacramental do século XVII para as estratégias comerciais seculares do século XVIII, e a inclusão cívica e a exclusão racial complementares do século XIX.

Antes de 1600 em Pernambuco e Bahia, eles vieram especialmente como serviçais qualificados que se identificavam mais com seus senhores como patrões do que acontecia na África, exceto como estratégias figuradas de clientela. Quando números maiores de escravizados chegaram diretamente da África no século XVII, as ondas de escravos de regiões limitadas de lá permitiram a eles criar sentidos de comunidade baseados nas familiaridades de suas origens, mas eles usaram os sacramentos da igreja para mascarar a troca, para afirmar identidades independentes de seus senhores, mulheres, em particular, costumes domésticos, e homens, em maneiras mais públicas.

Minas Gerais, seguida pela cidade do Rio, regiões de cultivo de açúcar em volta dela e, eventualmente, o norte cultivador de algodão agruparam a maioria dos trabalhadores que construíram suas economias e povoaram suas sociedades 
de maneira muito mais comercial; ali essas gerações fundadoras se apropriaram das leis de propriedade e das especializações ocupacionais para esculpir comunidades nascentes a partir da instabilidade da vida sob a escravidão capitalista, as mulheres convertendo os laços domésticos de suas predecessoras por contratos de manumissão, e os homens agrupando-se em volta de seus valores de propriedade para seus senhores. Seus senhores, por sua vez, compreenderam suas habilidades como inerentes a etnias imaginárias que refletiam onde eles haviam sido capturados ou comprados, mais do que quem eles haviam sido. Numa relação de dominação teoricamente total, os escravos criaram identidades para si mesmos, de forma que seus senhores não pudessem perceber, ou explorando para propósitos pessoais as identidades atribuídas a eles pelos senhores. O que resplandecia mais exoticamente como "africanos" constantemente aparecia como ouro apenas para aqueles a quem os escravos enganaram.

No século XIX, o "abrasileiramento" das plantations cafeeiras de São Paulo e cercanias simbolizou as estratégias de construção de uma memória coletiva de uma África não mais relembrada pessoalmente pelos escravos e com menos experiência direta da África. Nesse último estágio da memória das conexões escravizantes no Brasil, menos e menos pessoas vieram de origem africana suficientemente similar, ou individualmente estável, para suprir identidades ambíguas de qualquer tipo; a escravização espalhada por toda a África estava impulsionando mais e mais pessoas, através de sucessões desnorteadas de afiliações marginais a comunidades estranhas, para algo que eles nunca haviam conhecido.

As pequenas minorias de jovens, muitos deles praticamente recém saídos de infâncias severamente rompidas, encontraram algumas poucas comunidades muito úteis, até reconhecíveis, entre uma multiplicidade de micronações no Rio, distintas das vagamente bantu na mistura poliglota da África Ocidental na Bahia. Estas experiências significaram muito para o povo que chegou ali da África central. O amálgama de africanos realocados nas províncias centrais do Brasil imperial para plantar, cuidar e colher o café ao lado de afro-brasileiros transferidos para ali, advindos do norte, criou uma consciência da força de trabalho de uma nova espécie, de natureza brasileira, da carga da labuta conjunta nos estados cafeeiros.

No nordeste, a linguagem antiga da religião foi ressuscitada nas comunidades em formação, uma vez mais através da aplicação dos símbolos do candomblé que ondas de imigrantes relativamente coerentes haviam trazido da África para as circunstâncias do Brasil, enquanto as restrições trazidas pela escravidão erodiam e os sentidos cívicos de sociedade substituíram a conformidade religiosa. Este abrasileiramento da África encontrou os desafios do crescimento da consciência 
racial no Brasil, uma vez que os afro-brasileiros generalizaram os elementos específicos dos quais se apropriaram para construir uma imagem do continente lembrado genérica e publicamente, diferentemente dos grupos de primeiros africanos que recordavam a partir de suas experiências pessoais de família e outras associações.

Enquanto história, os escravos adaptaram suas lutas por identidade no Brasil às circunstâncias mutantes nas quais se encontraram: para a escravidão por si mesma em formas que variam da cidade ao campo e de região a região; sob senhores que adaptaram suas estratégias da moldura religiosa para a comercial, e para o cívico e o nacional do século XVI ao século XIX; das muitas habilidades e experiências em África das gerações de adultos fundadores ao potencial não formado das crianças que os seguiram próximo ao fim do mercado; da relativamente estreita área de regiões africanas envolvidas no início do tráfico a rompimentos de proporções continentais quando próximo de seu final; da abertura que as gerações fundantes encontraram em cada capitania do Brasil para comunidades de escravos cada vez mais estabelecidas nas quais os que chegaram depois tiveram que encontrar lugar para si.

Nós somos todos produtos de nossos passados, enquanto nos adaptamos a experiências para compreendermos as circunstâncias que enfrentamos no presente conforme elas se descortinam. Nesse complexo entre-jogo de estratégias de retenção que trabalha recriando-a nova para fazê-las funcionar, e lembrandose delas como passado para autenticá-las, os primeiros escravos a chegarem ao Brasil tinham somente a África a recorrer; seus sucessores olharam para trás, para os predecessores americanos, adaptando as conexões religiosas para propósitos comerciais e, estas, por sua vez, em clamores cívicos, cada geração relembrando a África de maneiras mais e mais amplas do que esta chegou a significar para eles enquanto escravos na América.

Recebido: 14/02/2011 - Aprovado: 20/04/2011. 